\title{
Article \\ Experimental Study of Fuel Consumption and Exhaust Gas Composition of a Diesel Engine Powered by Biodiesel from Waste of Animal Origin
}

\author{
Dariusz Kurczyński ${ }^{1}$, Grzegorz Wcisło ${ }^{2}$ and Piotr Lagowski ${ }^{1, *(\mathbb{D})}$ \\ 1 Department of Automotive Vehicles and Transportation, Faculty of Mechatronics and Mechanical \\ Engineering, Kielce University of Technology, 25-314 Kielce, Poland; kdarek@tu.kielce.pl \\ 2 Department of Bioprocess Engineering, Power Engineering and Automation, Faculty of Production and \\ Power Engineering, University of Agriculture in Krakow, 30-149 Krakow, Poland; \\ grzegorz.wcislo@ur.krakow.pl \\ * Correspondence: p.lagowski@tu.kielce.pl; Tel.: +48-41-3424332
}

check for updates

Citation: Kurczyński, D.; Wcisło, G.; Łagowski, P. Experimental Study of Fuel Consumption and Exhaust Gas Composition of a Diesel Engine Powered by Biodiesel from Waste of Animal Origin. Energies 2021, 14, 3472. https://doi.org/10.3390/en14123472

\section{Academic Editor: Sławomir}

Wierzbicki, Kamil Duda and Maciej Mikulski

\section{Received: 20 April 2021}

Accepted: 7 June 2021

Published: 11 June 2021

Publisher's Note: MDPI stays neutral with regard to jurisdictional claims in published maps and institutional affiliations.

Copyright: (c) 2021 by the authors. Licensee MDPI, Basel, Switzerland. This article is an open access article distributed under the terms and conditions of the Creative Commons Attribution (CC BY) license (https:// creativecommons.org/licenses/by/ $4.0 /)$.

\begin{abstract}
The use of biofuel is one method for limiting the harmful impact of diesel engines on the environment. It is also a way of gradually becoming less dependent on the depleting petroleum resources. New resources for producing biodiesel are currently being sought. The authors produced esters from animal fat waste, obtaining a fuel that can power diesel engines and identifying a way to utilise unnecessary waste. The animal fat methyl ester (AME) was produced using a reactor constructed for non-industrial ester production. The aim underlying this paper was to determine whether a diesel engine can be fuelled with AME biodiesel and to test this fuel's impact on exhaust gas composition and fuel consumption. Fuelling a Perkins 1104D-44TA engine with AME biodiesel led to a reduction in the smoke opacity of the exhaust gas as well as in carbohydrate, particulate matter, and carbon monoxide concentrations. The carbon dioxide concentrations were similar for biodiesel and diesel fuel. Slight increases in nitrogen oxides concentrations and brake-specific fuel consumption were found for AMEs. An engine can be fuelled with AME biodiesel, but it is necessary to improve its low-temperature properties.
\end{abstract}

Keywords: animal fat waste; biodiesel; second-generation biofuel; animal fat esters; diesel engine; fuel consumption; exhaust gas composition

\section{Introduction}

In the literature, many important reasons justifying the need to use biofuels are mentioned [1-8]. The most important ones are the need to limit greenhouse gas emissions, the depletion of fossil fuel resources, and the need to reduce dependence on states with fossil fuel resources. Furthermore, it is possible to introduce a new generation of fuels, the production of which will not affect food prices [9-15].

Plants have the ability to store solar energy in organic matter, to some degree. Vegetable biomass can be referred to as a primary biomass and is obtained when photosynthesis reacts with carbon dioxide and water using solar energy. Animal biomass can be referred to as a secondary biomass; it is easier and definitely more effective to use vegetable biomass. However, animal biomass is often a waste product of the food industry and is difficult to utilise. It can therefore be used for fuel production, as proposed in this paper.

There are two main reasons behind the search for alternate fuels to power diesel engines. The first is limited conventional fuel resources. Moreover, these resources are gradually being exhausted. People are aware that they may be depleted. Moreover, not everyone has access to petroleum, natural gas, or carbon resources. The second reason for the search and use of alternate fuels, perhaps even more important today, is the need to limit human civilisation's harmful impact on the environment. Energy consumption 
has a huge impact on the environment, and transport and diesel engines comprise an extremely high proportion of this consumption. Harmful compounds are released into the environment during the combustion of conventional fuel. The use of biofuels in transport is meant to reduce dependence on petroleum and to limit the harmful impact of diesel engines on the environment.

The European Union's policy puts a strong emphasis on gradually increasing the share of renewable energy in the total energy demand of member states [16-21] in order to provide environmental, economic, and social benefits in the future. The most important benefits include reducing greenhouse gas emissions and preventing climate change, reducing dependence on energy resource supplies from outside the EU, and contributing to technological and economic development. The overarching objective is to provide adequate living conditions for current and future generations.

Currently, European road transport mainly relies on diesel engines. Fatty acid esters can constitute an alternative fuel to power these engines. If they meet the normative requirements, they can be used in their pure form or as an additive to diesel fuels. There are requirements that impose the use of esters as an additive to diesel fuels. The best known and most widely used technology is for obtaining esters from vegetable oil fatty acids. The following oils are most often used for this purpose: rapeseed, soybean, sunflower, and palm [22-30]. This solution is not currently promoted due to food prices. Raw materials are being sought which are not used in food production, but which can used for biodiesel production [31,32]. There is research being conducted on producing esters from various plants which are unsuitable for food production [33-41]. Furthermore, the technology of obtaining esters from algae is currently being developed [42-49]. Algae are photosynthesising micro-organisms with low requirements for growth. In the future, they can may become an important source of fuel. Moreover, organic matter of various origins could be utilised in the production of biogas [50-54]. It can also be used as an alternative fuel for powering engines [55-59]. There is also research on generating new plant species with the use of genetic engineering. The aim is to obtain plants that will be able to assimilate more carbon dioxide at the cultivation stage. This will increase the capture of carbon dioxide from the atmosphere and the storage of carbon in organic matter. In the future, this can be a good method of limiting the impact of $\mathrm{CO}_{2}$ on the greenhouse effect and climate change.

Increasing human population, the advancement of civilisation, and better living standards are contributing to a substantial increase in the quantity of various types of waste generated by humans. The aim is to utilise this waste, which includes large quantities of organic matter, in an economic manner to the greatest possible extent. One method for utilising it is to process it into biofuels; the fuels obtained from such raw materials are classified as second-generation biofuels.

Various types of biological waste can constitute the raw material for ester production: the waste can derive from agriculture, food preparation, the food industry, and other branches that utilise organic matter. This can include waste in the form of plant organic matter and animal waste. The acquisition of biofuel from plant matter is obviously better developed, as less research has been carried on the acquisition of biofuel from animal fats. Some researchers [60-66] have used waste oil from food preparation. Uddin et al. used waste coffee oil to produce esters [67]. Based on tests done on the physical and chemical properties of the esters obtained, it was ascertained that they can constitute fuel for diesel engines.

Esters can also be produced from animal fats [68,69]. They are produced from animal waste [70-72]. The basic advantage of this raw material is its low cost. In [73], the raw material for biodiesel production included chicken and pig fat residue. The tested properties of this biodiesel were compliant with the requirements of the standards ASTM D6751 and EN 14214. Alptekin et al. [74] produced corn oil esters and chicken fat esters in the same system. Animal fat methyl esters performed slightly worse in comparison to corn oil methyl esters. The production costs of esters obtained from animal waste were lower, 
however, which is due to the lower cost of the raw material. The authors of this paper demonstrated similar fuel properties of the methyl esters they produced from various raw materials. They were compliant with the requirements specified for biodiesel fuel in the standard ASTM D6751. Encinar et al. [75] produced biodiesel from three animal fats-slaughterhouse waste-that featured various quantities of free fatty acids. A product with $97.3 \% \mathrm{~m} / \mathrm{m}$ mass content of esters was obtained as a result of transesterification. Most properties of the produced esters were compliant with the standard EN 14214. It was demonstrated in [76] that biodiesel produced from chicken fat waste was a suitable substitute for diesel produced from edible vegetable oils. The properties of chicken fat methyl ester were compliant with the ASTM D6751 standard for biodiesel and it was determined to be a suitable substitute for conventional diesel fuel. Its primary advantage was reported to be its availability and low cost.

This paper's authors encountered a problem related to the utilisation of animal waste: there are not many publications that present the results of tests of commonly used engines fuelled with esters produced from animal waste. Mikulski et al. [68] obtained methyl esters from pig lard in a laboratory. The physical and chemical properties of some ester mixtures and diesel fuel (DF) were tested-B25, B50, B75-as were pure esters and DF. An engine test bench was used to fuel a four-cylinder engine with the mixtures and with DF.

Whilst other researchers usually obtain esters from new raw materials under laboratory conditions, this paper's authors produced esters from animal fat waste. The owner of a plant processing animal hides pointed to the problem of residual waste. The authors decided to use this waste as the raw material for ester production. Esters were produced with the use of a reactor built and patented by Grzegorz Wcisło, one of the co-authors of the paper (Patent Office of the Republic of Poland, Patent No. 218554); they were tagged with the abbreviation AME. The esters, in their pure form without any additives, were used to fuel a diesel engine. The main objective of the first tests conducted by the authors on the AMEs used as fuel was to determine the possibility of fuelling an engine as well as their impact on the engine's fuel consumption and concentration of primary harmful exhaust gas components.

\section{Materials and Methods}

\subsection{Tested Fuel}

The tested esters were obtained from animal fats. The raw material used for ester production was waste remaining after the processing of animal hides used in the shoe and clothing industries. The remaining fatty waste is difficult to utilise and would otherwise require disposal. This paper's authors used this waste to produce fuel that can then be used to fuel diesel engines. Methyl alcohol and a $\mathrm{KOH}$ alkaline catalyst were used, resulting in animal methyl esters. The tested selected physical and chemical properties of the AMEs and of the DF used for engine testing are presented in Table 1. The AMEs have a much higher cetane number than commercial fuel. Their heating value is approximately $10.87 \%$ lower, which results from the content of oxygen atoms in the ester particles. Furthermore, they are characterised by a substantially higher viscosity and slightly greater density. The AMEs have a substantially higher flash point, which means that they are safer to use. On the other hand, they contain more water and have substantially worse low-temperature properties than DF. Engine testing was conducted using esters without any additives to improve their physical and chemical properties, including low-temperature properties. The cold filter plugging point (CFPP) of the tested DF was $-27^{\circ} \mathrm{C}$, whereas the esters' CFPP was $13{ }^{\circ} \mathrm{C}$. This means that the possibility of fuelling an engine with pure AMEs is limited unless additives to reduce the cold filter plugging point are used. It seems that biodiesel obtained from animal fatty acids features large quantities of palmitic acids. These acids are integrated at a temperature of $+25^{\circ} \mathrm{C}$. During engine testing, the esters were heated up and maintained at a temperature of $40^{\circ} \mathrm{C}$. 
Table 1. Physical and chemical properties of AME biodiesel and diesel fuel used in the research.

\begin{tabular}{|c|c|c|c|}
\hline \multirow{2}{*}{ Property } & \multirow{2}{*}{ Method } & \multicolumn{2}{|c|}{ Value } \\
\hline & & Diesel Fuel & AME \\
\hline Cetane number $(\mathrm{CN})$ & EN ISO 5165 & 51.7 & 55.4 \\
\hline Higher heating value, $\mathrm{MJ} / \mathrm{kg}$ & PN-C-04375-3 & 46.32 & 42.23 \\
\hline Lower heating value, $\mathrm{MJ} / \mathrm{kg}$ & PN-C-04375-3 & 43.34 & 38.67 \\
\hline Viscosity at $40^{\circ} \mathrm{C}, \mathrm{mm}^{2} / \mathrm{s}$ & PN-EN ISO 3104 & 2.11 & 4.32 \\
\hline Density at $15^{\circ} \mathrm{C}, \mathrm{g} / \mathrm{cm}^{3}$ & PN-EN ISO 12185 & 0.828 & 0.883 \\
\hline Flash point, ${ }^{\circ} \mathrm{C}$ & EN ISO 2719 A & 58.5 & 116.2 \\
\hline Water content, $\mathrm{mg} / \mathrm{kg}$ & EN ISO 12937 & 24 & 84 \\
\hline Cold filter plugging point, ${ }^{\circ} \mathrm{C}$ & EN 116 & -27 & 13 \\
\hline Lubricity (WSD), $\mu \mathrm{m}$ & PN-EN ISO 12,156 (1) & 408 & 614 \\
\hline HPLC total aromatics, $\%(\mathrm{~m} / \mathrm{m})$ & $\begin{array}{c}\text { Infrared analysis (instrument TD } \\
\text { PPA-PetroSpec by PAC) }\end{array}$ & 16.3 & - \\
\hline HPLC PNA aromatics, $\%(\mathrm{~m} / \mathrm{m})$ & $\begin{array}{l}\text { Infrared analysis (instrument TD } \\
\text { PPA-PetroSpec by PAC) }\end{array}$ & 1.4 & - \\
\hline FAME content, \% (v/v) & $\begin{array}{l}\text { (DF-Irox Diesel apparatus, } \\
\text { AME-PN-EN 14103) }\end{array}$ & 0.1 & 100 \\
\hline
\end{tabular}

The esters from animal fat waste were produced at the "BioEnergia" Małopolskie Centre for Renewable Energy Sources. The GW-200 reactor [77] built by one of this paper co-authors was used for this purpose. The reactor (Figure 1) can be used to produce esters from various raw materials on a non-industrial scale and is mainly dedicated for individuals, farmers, transport companies, and others. The basic technical data of the GW-200 reactor are shown in Table 2.

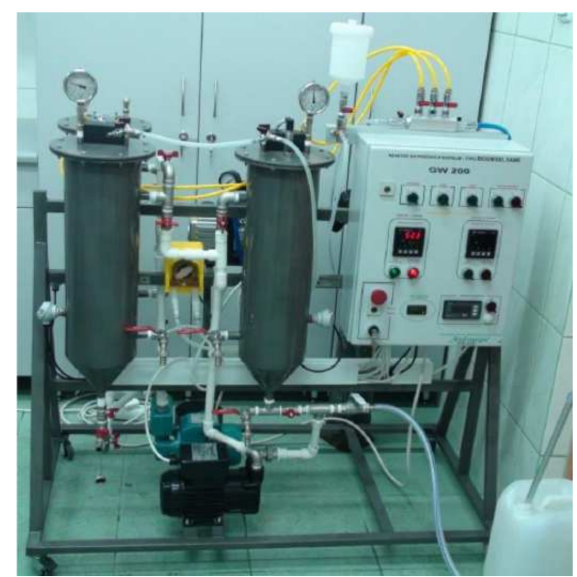

Figure 1. GW 200 reactor making vegetable oil esters to fuel diesel engines [77].

Table 2. Technical data of the GW-200 reactor.

\begin{tabular}{ccc}
\hline Parameter & Unit & Value \\
\hline Efficiency per cycle & $\mathrm{dm}^{3}$ & 50 \\
Production time per cycle & $\mathrm{h}$ & 1.5 \\
Supply voltage & $\mathrm{V}$ & 230 \\
Process temperature & ${ }^{\circ} \mathrm{C}$ & $60 / 120$ \\
Rated power per cycle & $\mathrm{kWh}$ & $5.24 / 5.15$ \\
Type of catalyst & - & basic/acidic \\
Process & - & periodic or semi-continuous \\
Type of process & - & single-stage or two-stage \\
\hline
\end{tabular}

The properties of vegetable oils and animal fats depend on the composition and system of fatty acids included in the structure of the triglycerides. In order to determine 
the fatty acid composition, the waste fat obtained from animal hides was subjected to chromatographic tests, carried out on a stand equipped with a Thermo Scientific TRACE GC Ultra gas chromatograph and a chromatographic column. The exact composition of the animal hide fatty acids is shown in Figure 2. As results from the data contained in this figure, three fatty acids-palmitic, stearic, and linoleic-constitute about $91 \%$ of the acids contained in the fat from which the biofuel was produced. Figure 3 presents a model of the transesterification process on the basis of which the stoichiometric amount of substrates needed for the production of AME biodiesel was determined. The model contains a triglyceride particle from which the fat used in the production of biodiesel is composed.

The degree of conversion of waste fat from the leather industry into esters through the authors' proprietary fatty acid methyl ester (FAME) production technology and the GW-200 reactor was $98.7 \%(\mathrm{~m} / \mathrm{m})$. This proves that very high purity esters were obtained that meet the requirements of EN-PN 14214, which states that the FAME content of the fuel must be at least $96.5 \%(\mathrm{~m} / \mathrm{m})$.

\subsection{Purpose and Scope of Experimental Testing}

The tests compared an engine fuelled with either pure AMEs or DF on an engine test bench. The tests aimed to find the effect of using second-generation biofuel, i.e., methyl esters obtained from animal fat waste, on Perkins 1104D-44TA engine fuel consumption and emissions. The engine's operating indicators when fuelled with AMEs were compared to those obtained when fuelled with DF, for which the engine was initially adapted. During the tests, the engine was operating according to the load specification for two crankshaft rotation speeds: 1400 and $2200 \mathrm{rpm}$. The former is the crankshaft rotation speed, at which the engine has maximum torque. The latter shows the crankshaft speed, at which the engine produces the maximum output. The measurements were taken for the whole engine load range at 1400 and $2200 \mathrm{rpm}$ crankshaft rotation speeds. Under the established engine operating conditions, which were the same for AMEs and DF, the following exhaust gas concentrations were measured: carbon monoxide $(\mathrm{CO})$, carbon dioxide $\left(\mathrm{CO}_{2}\right)$, nitrogen oxides $\left(\mathrm{NO}_{\mathrm{x}}\right)$, total hydrocarbon content (THC), particulate matter $(\mathrm{PM})$, and oxygen $\left(\mathrm{O}_{2}\right)$. Furthermore, the smoke opacity of the exhaust gas was measured. For testing of the particulate matter concentration, the measurements were conducted separately for the content of soot and soluble organic fractions in the exhaust gasses. The measurements were conducted under the exact same engine operating conditions in order to compare the concentrations of exhaust gas components in the engine fuelled with AMEs versus DF.

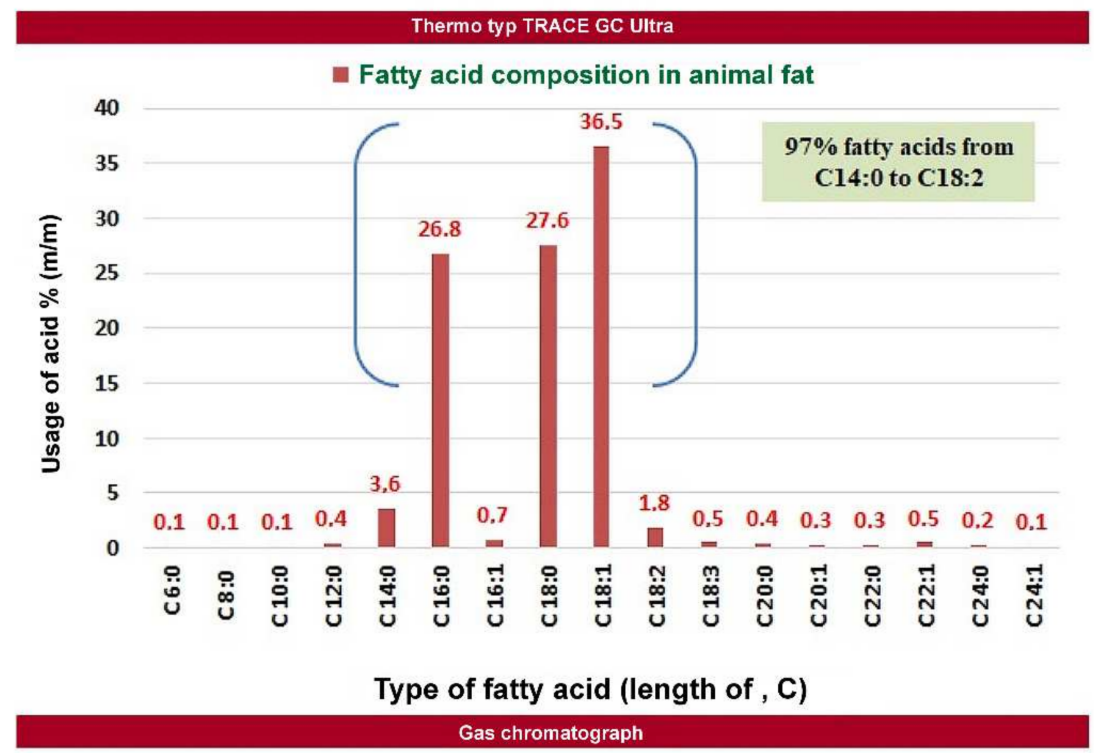

Figure 2. Average fatty acid composition of waste fat obtained from animal hides. 
Methanol + katalys $=$ Potassium methanolan $\mathrm{CH} \mathrm{OH}+\mathrm{KOH}$

3 particles - Methanol

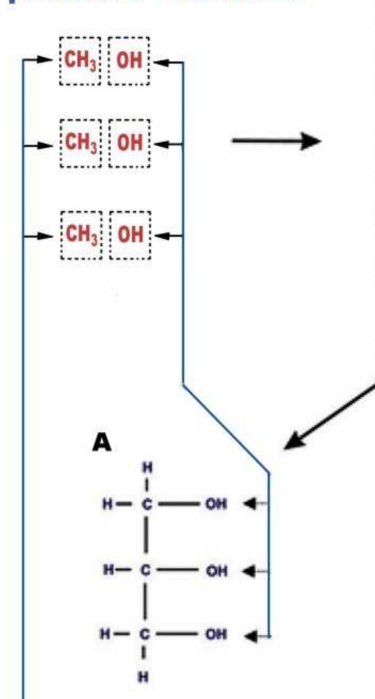

Glycerine side product

1 particle of animal fat

Palmic acid

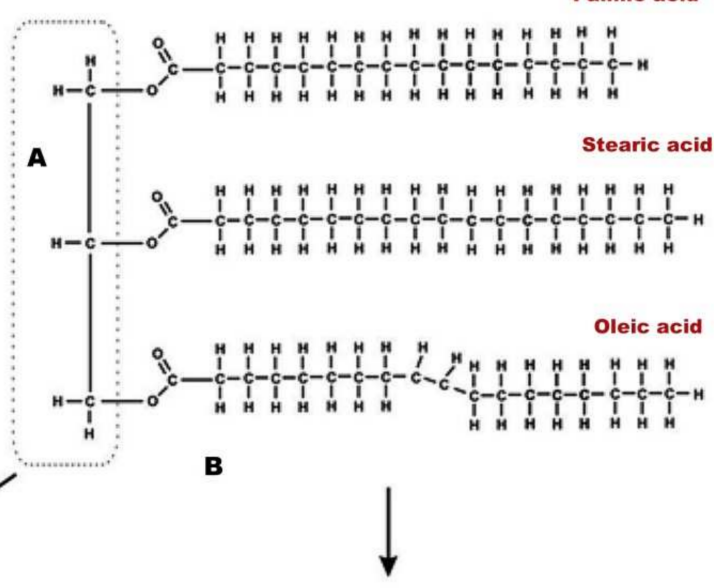

Palmic acid methyl ester

B

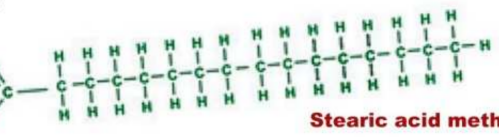

Stearic acid methyl ester

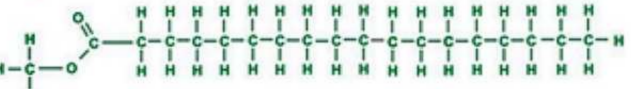

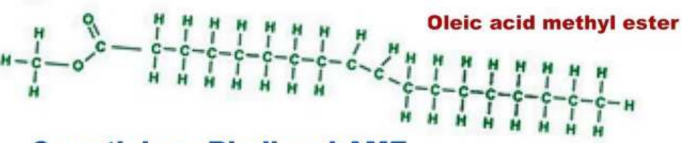

3 particles - Biodiesel AME

Figure 3. Model of obtaining AME esters from typical triglyceride from animal fat composed of palmitic, stearic and linoleic acids.

\subsection{Engine Selected for Testing}

The experimental testing was conducted with a Perkins 1104D-44TA engine, a fourcylinder diesel engine for off-road vehicles. The engine satisfies the requirements of Stage IIIA and EPA Tier 3 standards. The engine is used in tractors and various types of working machinery, among other purposes. The basic specifications of the Perkins 1104D-44TA engine are shown in Table 3.

Table 3. Basic technical data of the Perkins 1104D-44TA diesel engine [78].

\begin{tabular}{cc}
\hline Parameter & Value \\
\hline Cylinder layout & Inline \\
Cylinder count & 4 \\
Injection type & Direct \\
Power supply type & Delphi DP310 rotary pump \\
Maximum engine power & $75 \mathrm{~kW}$ \\
Maximum power rotational speed & $2200 \mathrm{rpm}$ \\
Maximum engine torque & $416.0 \mathrm{Nm}$ \\
Maximum torque rotational speed & $1400 \mathrm{rpm}$ \\
Engine displacement & $4.4 \cdot 10^{-3} \mathrm{~m}^{3}$ \\
Cylinder diameter & $105 \mathrm{~mm}$ \\
Piston stroke & $127 \mathrm{~mm}$ \\
Compression ratio & 18.2 \\
Air supply system & Turbocharger, intercooler
\end{tabular}




\subsection{Experimental Setup}

The testing was conducted on an engine test bench with a Perkins 1104D-44TA diesel engine and an AMX-200/6000 eddy current brake from ELEKTROMEX CENTRUM. A common frame was used to accommodate the engine, the brake, the controls, and the engine operation supporting systems. The brake can receive an output of $200 \mathrm{~kW}$ from the engine and can transfer $700 \mathrm{Nm}$ of torque. A desktop computer was installed on the engine test bench. The computer software made it possible to control and visualise the course of the test. The engine's fuel consumption was measured by a mass fuel dosimeter from Automex. Air consumption measurements were taken with a mass flowmeter from ABB. The diagrams of the engine test bench used in the investigations are shown in Figure 4. The Perkins 1104D-44TA engine's operation was controlled via a control module and computer. The engine test bench's control module allows the engine's operating speed and load conditions to be adjusted. It controls the operating conditions of the engine and the brake and diagnoses the station's correct operation. The computer allows the tested engine's operating parameters to be recorded and archived. The basic metrological parameters of the test bench are shown in Table 4 .

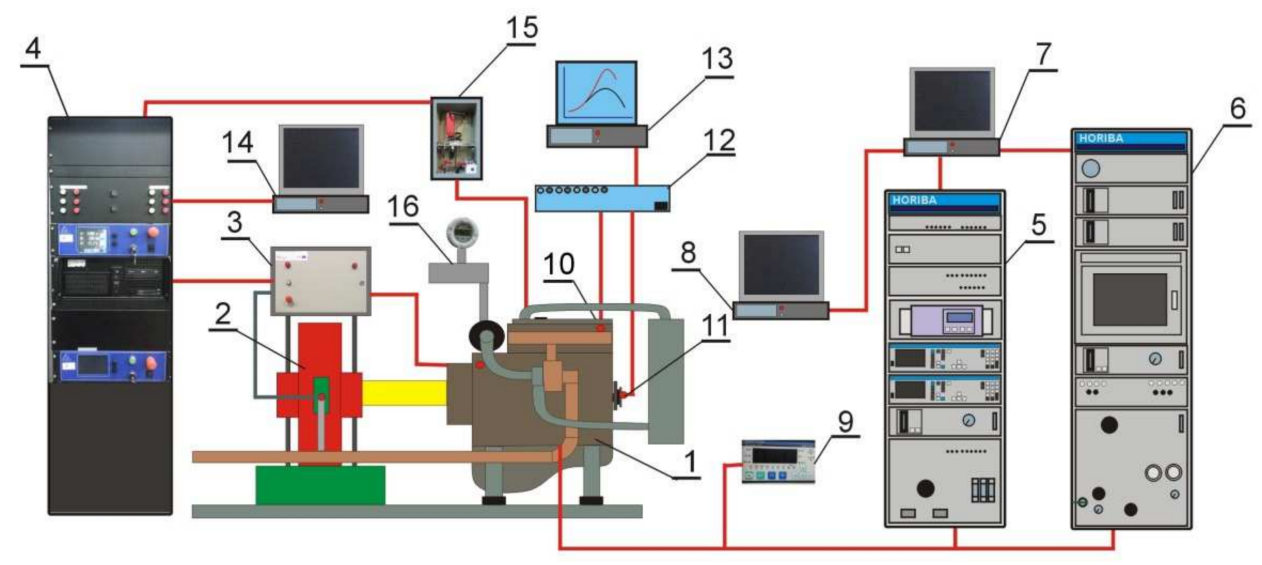

Figure 4. Set-up of the test stand: 1-Perkins 1104D-44TA engine, 2-Automex AMX-200/6000 brake, 3-measurement module, 4-measurement cabinet with the control system, 5-Horiba Mexa 1230PM particulate analyser, 6-Horiba Mexa 1600DEGR exhaust gas analyser, 7-computer for the control of the Mexa 1230PM analyser operation, 8-computer used to coordinate the exhaust measurements analysis and archive the results of emission measurements, 9-Horiba AFR Mexa-730 Analyser $\lambda$ device for measuring the excess air coefficient, 10-AVL engine cylinder pressure sensor, 11-AVL 365C engine crank angle encoder, 12-AVL Indicom 612 dynamic variable quantity indexing system, 13-computer used to control the measurements of rapidly varying quantities and to archive measurement results, 14-computer used to control the stand parameters and to archive test results, 15-fuel mass dosing device Automex ATMX2040, 16-SENSYFOLW iG air flow meter by ABB [78].

Table 4. Basic metrological parameters of the experimental stand [78].

\begin{tabular}{cccc}
\hline Measured Parameter & Measurement Range & Measurement Accuracy & Measurement Resolution \\
\hline Rotation speed & $0-6000 \mathrm{rpm}$ & $\leq 1 \mathrm{rpm}$ & $1 \mathrm{rpm}$ \\
Torque & $0-700 \mathrm{Nm}$ & $1 \%$ of full scale & $0.001 \mathrm{Nm}$ \\
Fuel consumption & $0-180 \mathrm{~kg} / \mathrm{h}$ & $0.1 \%$ of measured value & $0.001 \mathrm{~g} / \mathrm{s}$ \\
Air consumption & $0-750 \mathrm{~kg} / \mathrm{h}$ & $0.2 \%$ of measured value & $0.001 \mathrm{~kg} / \mathrm{h}$ \\
\hline
\end{tabular}

\subsection{Measurement Instrumentation}

The measurements of the component concentrations of engine exhaust gas were taken during the bench testing using exhaust gas test analysers from Horiba: MEXA-1600 DEGR and MEXA-1230PM. The MEXA-1600DEGR analyser is used for continuous measurements of the concentrations of five components of diesel exhaust gas, namely $\mathrm{CO}, \mathrm{CO}_{2}, \mathrm{THC}$, 
$\mathrm{NO}_{\mathrm{x}}$, and $\mathrm{O}_{2}$ in real time. The MEXA-1230 PM analyser from Horiba can measure the mass concentration of particulate matter: soluble organic fractions (SOF), soot, and the total mass of soot and soluble organic fractions (PM). The analysers' exhaust gas sampling paths were compliant with the requirements of the ISO-8178 standard. The measurement of the $\mathrm{CO}$ and $\mathrm{CO}_{2}$ content of the exhaust gas in the MEXA-1600 DEGR measurement system was conducted by an analyser operating according to the non-dispersive infrared radiation absorption method (NDIR). The THC was measured with a flame ionisation detector. The $\mathrm{NO}_{\mathrm{x}}$ concentrations were measured based on the chemiluminescence detector (CLD) method. The $\mathrm{O}_{2}$ content of the exhaust gas was measured using a paramagnetic detector (PMD). The measurement of the mass soot concentration in the MEXA-1230PM analyser was conducted according to the diffusion charging method using a Model 3070A electric aerosol detector. Soluble organic fractions were measured using the flame ionisation method with two heated flame ionisation detector (FID) detectors, as the remainder of their signals for the exhaust gas tested at 47 and $191{ }^{\circ} \mathrm{C}$. The metrological parameters used for the analyser testing are presented in Table 5.

Table 5. Metrological parameters of the analysers employed in the tests [78].

\begin{tabular}{cccccc}
\hline $\begin{array}{c}\text { Component } \\
\text { Measured }\end{array}$ & Method & $\begin{array}{c}\text { Measurement Ranges } \\
\text { Min/Max }\end{array}$ & Repeatability & $\begin{array}{c}\text { Measurement } \\
\text { Resolution }\end{array}$ & Response Time \\
\hline $\mathrm{CO}$ & NDIR & $0-100 / 3000 \mathrm{ppm}$ & $\pm 1 \%$ of full scale & $0.1 \mathrm{ppm}$ & $3.0 \mathrm{~s}$ \\
$\mathrm{CO} 2$ & NDIR & $0-1 / 16 \%$ & $\pm 1 \%$ of full scale & $0.01 \%$ & $2.0 \mathrm{~s}$ \\
$\mathrm{THC}$ & Hot-FID & $0-100 / 20,000 \mathrm{ppm}$ & $\pm 1 \%$ of full scale & $0.1 \mathrm{ppm}$ & $2.0 \mathrm{~s}$ \\
$\mathrm{NO}_{\mathrm{x}}$ & $\mathrm{CLD}$ & $0-100 / 5000 \mathrm{ppm}$ & $\pm 1 \%$ of full scale & $0.1 \mathrm{ppm}$ & $0.01 \%$ \\
$\mathrm{O}_{2}$ & MPD & $0-10 / 25 \% \%$ & $\pm 1 \%$ of full scale & $0.01 \mathrm{mg} / \mathrm{m}^{3}$ & $3.0 \mathrm{~s}$ \\
$\mathrm{PM}$ & Soot: DCSOF: & $0-300 \mathrm{mg} / \mathrm{m}^{3}$ & $\pm 1 \%$ of full scale & & $3.0 \mathrm{~s}$ \\
\hline
\end{tabular}

The tested diesel engine's exhaust gas smoke opacity was measured with an AVL DiCom 4000 PL analyser. This analyser allows for measurement of exhaust gas smoke opacity with the use of the optical method. The exhaust gas smoke opacity is expressed as a percentage of exhaust gas opacity reduction, on a scale of $0 \%$ to $100 \%$, with a resolution of $0.1 \%$, or via the radiation absorption coefficient $k$ on a scale of 0 to $99.99 \mathrm{~m}^{-1}$, with a resolution of $0.01 \mathrm{~m}^{-1}$.

The test bench was equipped with an AVL IndiSmart 612 system for measuring fastchanging quantities. It can measure the pressure of the working medium in the cylinder of the tested engine. That is expressed as the function of the crankshaft rotation angle. The cylinder indication set used in the tests consisted of a data acquisition system, a piezoelectric pressure sensor in the engine's cylinder, and an engine crankshaft rotation angle encoder. The system utilised an AVL 365C photoelectric encoder with a resolution of 720 electric pulses per rotation cycle. This means that the measurements were taken every $0.5^{\circ}$ of crankshaft rotation. The system allows for multiplication of the signals, thereby enabling an increase in the measurement resolution to $0.1^{\circ}$ of crankshaft rotation. Furthermore, the system features the AVL Indicom Mobile 2012 programme. It is required for the system to operate and for visualisation, archiving, and analysis of the indicator charts.

\subsection{Development Methodology of the Experimental Test Results}

The engine operating indicators are arithmetic means from measurements taken under the established engine operating conditions. All engine operating indicators and parameters were recorded at the same time after the engine operating conditions were set for a given measurement point. The exhaust gas components were measured by MEXA1600 DEGR at a sampling frequency of five measurements per second. The particulate matter content in the exhaust gas was determined once per second with MEXA-1230 PM. The exhaust gas component values were saved in separate files for each set of established operating conditions. Other engine operating indicators and parameters, namely torque, 
output, hourly fuel consumption, crankshaft rotation speed, temperature and pressure in the engine functional systems-were measured in real time. The result files were saved for successive established measurement conditions. Once the engine operating conditions were set at each measurement point, the measurements were taken for approximately sixty seconds. The standard uncertainty of the arithmetic mean was calculated for the measured quantities $\mathrm{x}$ :

$$
\Delta x=\left[\frac{1}{n(n-1)} \sum_{i=1}^{n}\left(x_{i}-x\right)^{2}\right]^{\frac{1}{2}}
$$

where $x$ is the measured quantity average value, $x_{i}$ are the measured quantity successive measurements, and $\mathrm{n}$ is the number of the quantity measurements in a set.

The brake-specific fuel consumption (BSFC) of the Perkins 1104D-44TA engine fuelled with AMEs and DF was calculated as follows:

$$
\mathrm{BSFC}=\frac{\mathrm{FC}}{\mathrm{P} * 1000}
$$

where $\mathrm{P}$ is the engine power and FC is the hourly fuel consumption.

The brake thermal efficiency (BTE) of the Perkins 1104D-44TA engine, fuelled with AMEs and DF, was computed using the following formula:

$$
\mathrm{BTE}=\frac{3600 * \mathrm{P}}{\mathrm{FC} * \mathrm{LHV}}
$$

where $\mathrm{P}$ is the engine power, FC is the hourly fuel consumption, and LHV is the lower heating value.

The following combined uncertainty was designated for the calculated quantities:

$$
\Delta(\mathrm{w})_{\mathrm{c}}=\left[\sum_{\mathrm{i}=1}^{\mathrm{n}}\left(\frac{\delta \mathrm{w}}{\delta \mathrm{x}_{\mathrm{i}}} * \Delta \mathrm{x}_{\mathrm{i}}\right)^{2}\right]^{\frac{1}{2}}
$$

where $\mathrm{w}$ is the calculated quantity, $\mathrm{n}$ is the number of measured constituents, $\mathrm{x}_{\mathrm{i}}$ is the measured constituent, and $\Delta x_{i}$ are the standard uncertainties of the measured constituents.

The measurements, conducted under exactly the same engine operating conditions, allowed a comparison of the exhaust gas component concentrations in the tested engine between second-generation biofuel and DF. The calculations encompassed relative changes in the AME/DF exhaust gas component concentrations between the two fuels. The following dependency was used for this purpose:

$$
\Delta \mathrm{i}=\frac{\mathrm{i}_{\mathrm{AME}}-\mathrm{i}_{\mathrm{DF}}}{\mathrm{i}_{\mathrm{DF}}} \cdot 100 \%
$$

where $\Delta \mathrm{i}$ is the relative change in the $\mathrm{i}$ component concentration in the exhaust gas of the engine fuelled with AMEs compared with the engine fuelled with DF, $i_{\text {AME }}$ is the $i$ component concentration in the exhaust gas of the engine fuelled with AMEs, and $i_{D F}$ is the i component concentration in the exhaust gas of the engine fuelled with DF.

\section{Test Results and Analysis}

The testing of the operating indicators for the Perkins 1104D-44TA engine fuelled with AME biodiesel and conventional DF for comparison purposes was conducted under selected engine operating conditions. The hourly fuel consumption was measured under these conditions at the test bench with the use of the mass fuel flowmeter. The quantities, measured for the AME biodiesel, are compared with the DF quantities in Figure 5. The charts show that slightly higher fuel consumption was achieved for esters than for DF. This is a result of the lower heating value of esters, which generate oxygen atoms regardless of the raw material. Table 1 shows that the heating value of AMEs is $10.87 \%$ lower than 
the heating value of DF. The engine's brake specific fuel consumption was calculated by dividing fuel consumption by effective output at particular measurement points. The BSFC quantities calculated for the engine fuelled with AMEs and DF are presented in Figure 6. It is clear that the BSFC quantities are higher for AME biodiesel at each measurement point. An average increase in BSFC of $8.4 \%$ was recorded for the engine fuelled with AMEs at $1400 \mathrm{rpm}$, and an increase of $14.9 \%$ was found at $2200 \mathrm{rpm}$. This complies with what other researchers reported when fuelling an engine with vegetable fat esters in comparison to an engine fuelled with DF or DF and ester mixtures [79-81].
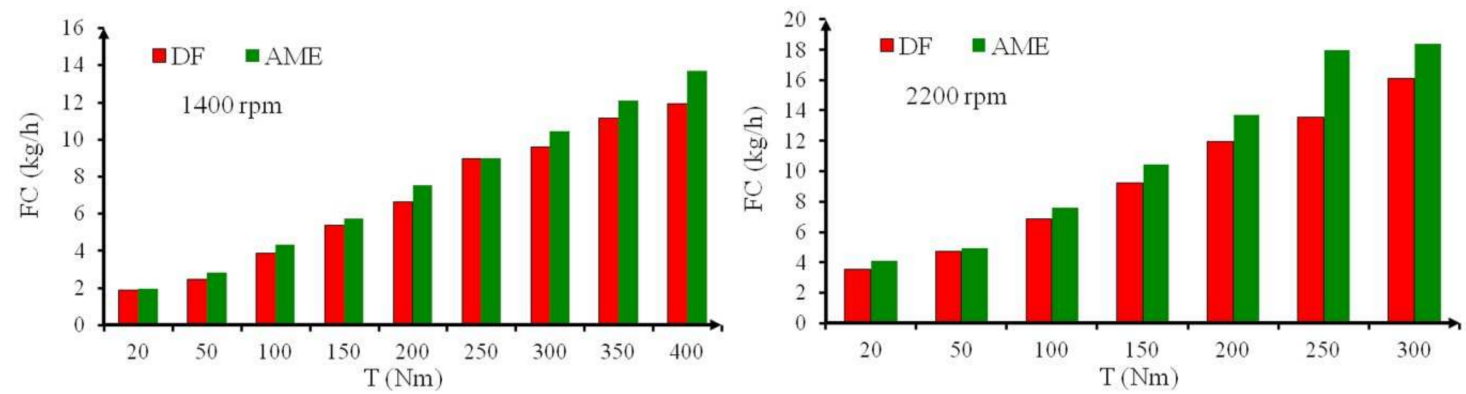

Figure 5. Hourly fuel consumption of the engine fuelled with AME and DF and operating at a load specification of 1400 and $2200 \mathrm{rpm}$.
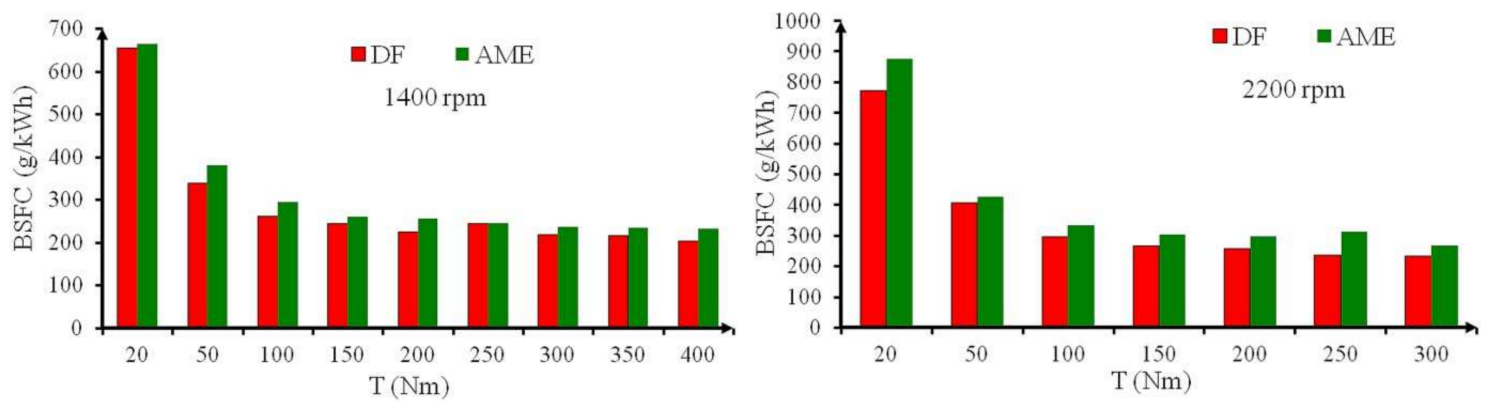

Figure 6. Brake specific fuel consumption of the engine fuelled with AME and DF and operating at a load specification of 1400 and $2200 \mathrm{rpm}$.

Brake thermal efficiency gives the assessment of the utilisation of energy supplied to engine cylinders with fuel. The BTEs of the Perkins 1104D-44TA engine fuelled with AMEs and DF were calculated. A comparison of BTEs at 1400 and $2200 \mathrm{rpm}$, as well as under various engine loads, is shown in Figure 7. Similar BTE values were obtained when fuelling the engine with the tested fuels. The average BTE was found to be $3.5 \%$ higher for AMEs at $1400 \mathrm{rpm}$ in comparison with the quantities recorded for DF. On the other hand, the average BTE was 2.3\% lower for AMEs at $2200 \mathrm{rpm}$ than for DF. The results obtained were probably affected by the change in crankshaft rotation speed. That alters the conditions of the formation of fuel-air mixture and its subsequent combustion. It is most likely that less favourable conditions prevailed for AME fuel at $2200 \mathrm{rpm}$. Modification of the injection process parameters would perhaps improve the energy efficiency when the engine is powered with AME esters. Further research aimed at optimising fuel injection parameters and developing optimal mixtures can be undertaken to improve energy efficiency when fuelling an engine with AMEs. The engine used in the testing was intended for use with DF.

The carbon monoxide content of the exhaust gas suggests an incomplete burning of the carbon included in the fuel's fractions. Figure 8 compares carbon monoxide concentrations in the exhaust from the Perkins 1104D-44TA engine fuelled with AMEs and DF. Lower CO concentrations in the exhaust gas of the tested engine were achieved at most measurement points when it was fuelled with AMEs. Higher CO quantities for AMEs when compared to DF were achieved only in the case of $1400 \mathrm{rpm}$ and high engine loads of 350 and $400 \mathrm{Nm}$. However, taking into account the results for all measurement points at $1400 \mathrm{rpm}$, the 
average reduction in $\mathrm{CO}$ concentration for AMEs amounted to approximately $7.2 \%$. On the other hand, at $2200 \mathrm{rpm}$, the average reduction in $\mathrm{CO}$ concentrations amounted to approximately $13.4 \%$ when fuelling the engine with AME biodiesel. These results suggest that AMEs burn more completely in an engine cylinder. Carbon monoxide oxidises better into carbon dioxide. This is related to the fact that esters feature oxygen atoms in their particles, and that oxygen is more readily available during the burning. Moreover, its content in ester particles increases the oxygen surplus in the fuel-air mixture prepared for combustion. This results from the slightly higher oxygen content in the exhaust gas when the engine is fuelled with AMEs. Figure 9 presents a comparison of oxygen concentrations in the exhaust gas when the engine is fuelled with AMEs versus DF. For measurements at $1400 \mathrm{rpm}$, the average $\mathrm{O}_{2}$ concentration was approximately $1.6 \%$ higher when the engine was fuelled with AME biodiesel when compared to DF. On the other hand, at $2200 \mathrm{rpm}$, the average oxygen concentration was approximately $3.2 \%$ higher. Other research has also confirmed the reduction in $\mathrm{CO}$ concentrations in the exhaust gas of engines fuelled with pure esters or esters mixed with DF [82-88].
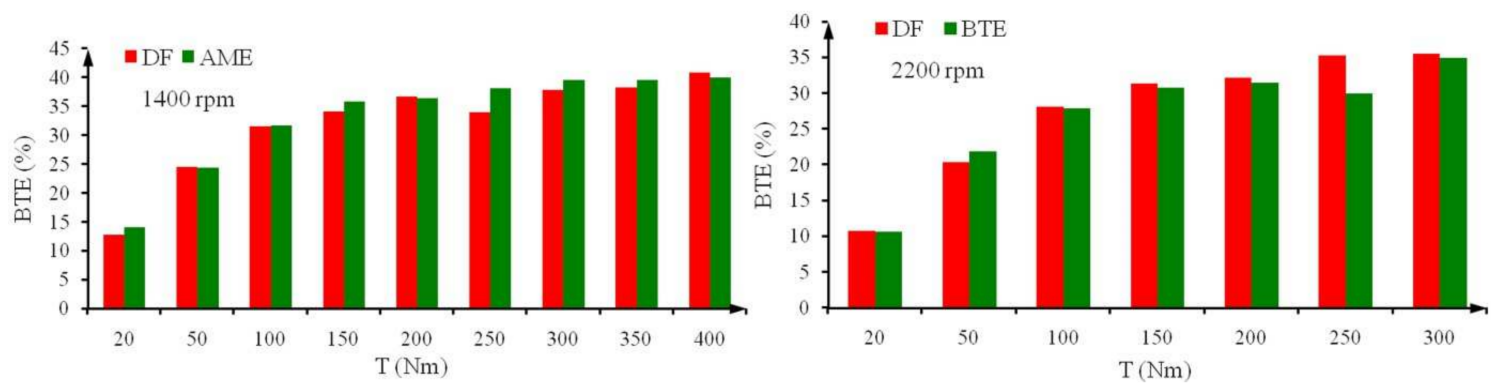

Figure 7. Brake thermal efficiencies of the engine fuelled with AME and DF and operating at a load specification of 1400 and $2200 \mathrm{rpm}$.
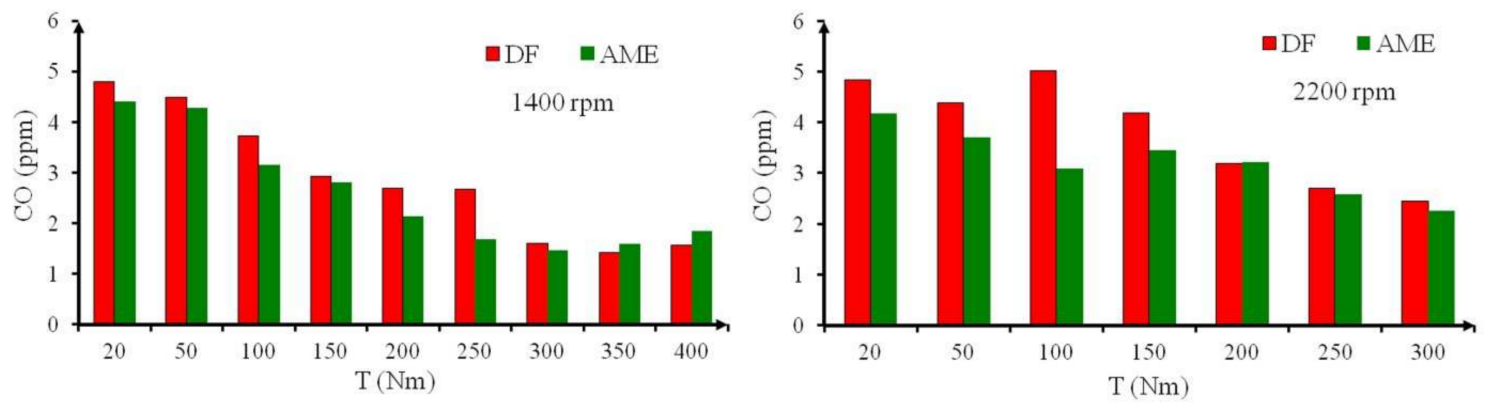

Figure 8. Comparison of CO concentrations in the exhaust gas of the engine fuelled with AME and DF and operating at a load specification of 1400 and $2200 \mathrm{rpm}$.
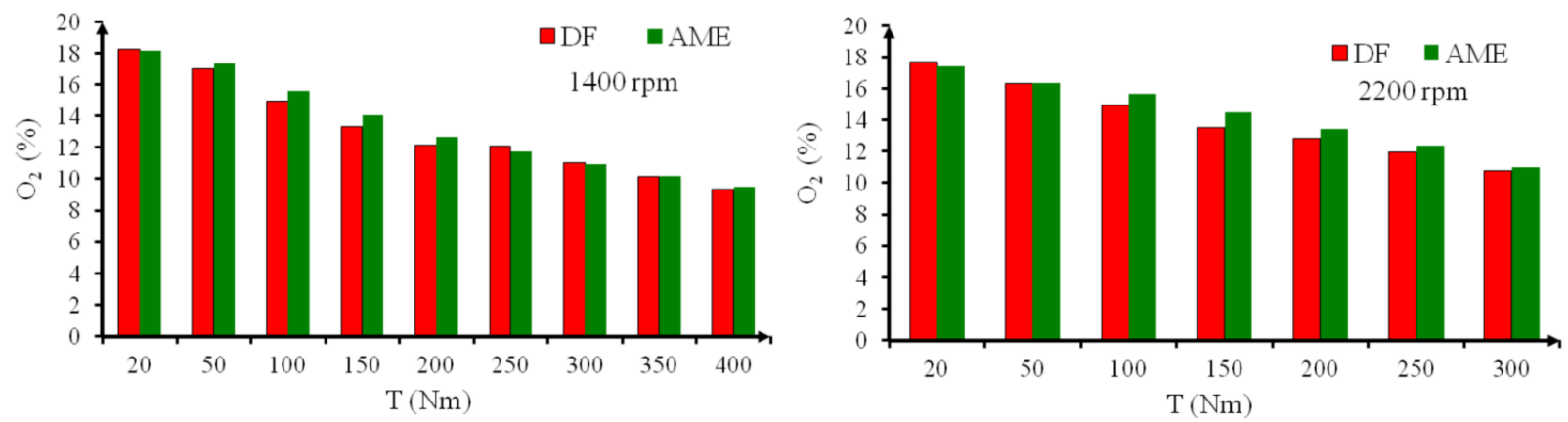

Figure 9. Comparison of $\mathrm{O}_{2}$ concentrations in the exhaust gas of the engine fuelled with AME and DF and operating at a load specification of 1400 and $2200 \mathrm{rpm}$. 
Carbon dioxide in exhaust gas is a product of complete carbon combustion. It is the factor most responsible for the increase in the greenhouse effect and climate change. The aim is to limit the quantities of $\mathrm{CO}_{2}$ introduced into the atmosphere through transport vehicles. The use of vegetable biofuel can help balance carbon dioxide emissions. One can assume that in the case of fuels obtained from animal organic matter, the balance will be less favourable. Figure 10 presents the measurement results of $\mathrm{CO}_{2}$ concentrations in the exhaust gas of the Perkins 1104D-44TA engine fuelled with AMEs and DF. The $\mathrm{CO}_{2}$ concentrations measured in the tests were very similar for AMEs and DF. For measurements at $1400 \mathrm{rpm}$, the $\mathrm{CO}_{2}$ concentration was slightly lower when fuelling the engine with AMEs, whilst at $2200 \mathrm{rpm}$ the average concentration was approximately $2 \%$ higher when fuelling the engine with AMEs in comparison to DF. Other publications have presented test results demonstrating a reduction in $\mathrm{CO}_{2}$ concentrations when using esters as an engine fuel $[83,89,90]$. There are also test results pointing to an increase in $\mathrm{CO}_{2}$ concentrations when using esters as an engine fuel [91,92]. These reported differences are not great or unequivocal. They may depend on the engine's operating conditions, the way it is adjusted, the type of power supply system, the composition of the tested fuels, or other factors.
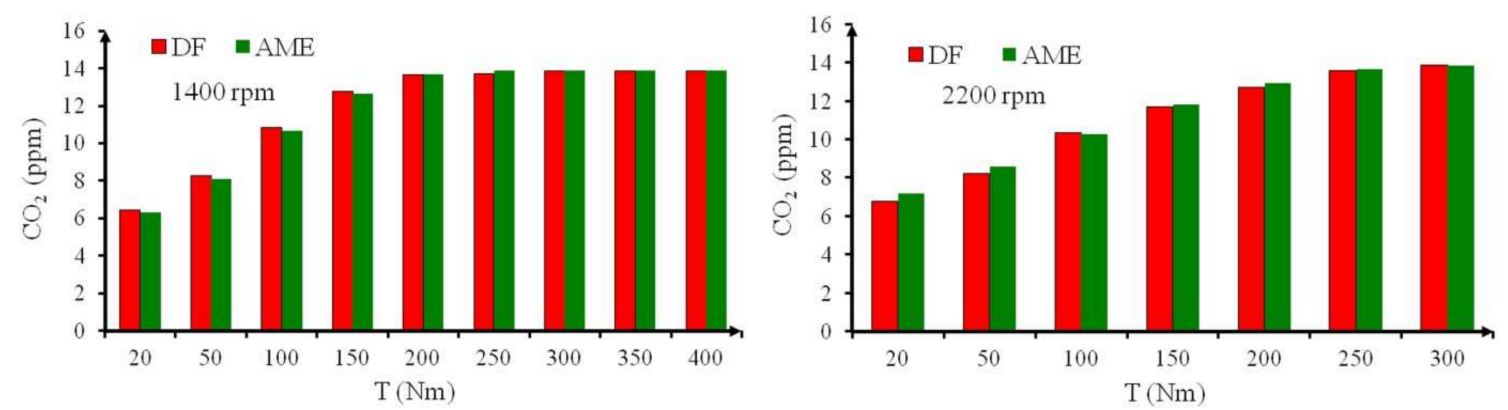

Figure 10. Comparison of $\mathrm{CO}_{2}$ concentrations in the exhaust gas of the engine fuelled with $\mathrm{AME}$ and DF and operating at a load specification of 1400 and $2200 \mathrm{rpm}$.

Nitrogen oxides emission is the primary problem of contemporary diesel engines. The use of esters usually contributes to increased nitrogen oxides emission [77,93-96]. The literature also features test results demonstrating a reduction in $\mathrm{NO}_{\mathrm{x}}$ concentrations when fuelling engines with esters $[97,98]$. Figure 11 provides a comparison of $\mathrm{NO}_{\mathbf{x}}$ concentrations in the exhaust gas of the Perkins 1104D-44TA engine fuelled with AMEs versus DF. At $1400 \mathrm{rpm}$, the average increase in $\mathrm{NO}_{\mathrm{x}}$ concentration in the exhaust gas amounted to approximately $15.6 \%$. On the other hand, at $2200 \mathrm{rpm}$ and under various loads, a slightly lower $\mathrm{NO}_{x}$ concentration was achieved at most measurement points when the engine was fuelled with AME biodiesel in comparison with DF. For measurements conducted at $2200 \mathrm{rpm}$ and with AME fuel, the average reduction in $\mathrm{NO}_{\mathrm{x}}$ concentrations amounted to approximately $4.4 \%$. The high cetane number and oxygen content in the ester particles affect the combustion of AMEs. These parameters contribute to a reduction in the fuel self-ignition delay and an acceleration of the combustion process. This in turn results in higher pressures. The differences in pressure waveforms are especially visible at small loads and slower rotation speeds. The duration of processes occurring in the engine's cylinder is reduced for higher rotation speeds, and these parameters do not contribute as much to the differences in AME and DF combustion. Figure 12 illustrates these conclusions with examples of engine cylinder pressure waveforms using AMEs and DF at selected measurement points. Similar observations were also confirmed by the $\mathrm{NO}_{\mathrm{x}}$ concentrations for esters and DF presented in [78]. The charts in Figure 11 clearly show that $\mathrm{NO}_{\mathrm{x}}$ concentrations for the selected fuels at a rotation speed of $1400 \mathrm{rpm}$ are substantially higher than those at $2200 \mathrm{rpm}$.

Figure 13 presents a comparison of the total hydrocarbon content in the exhaust gas of the Perkins 1104D-44TA engine fuelled with AME biodiesel and DF, operating at two different crankshaft rotation speeds and under various loads. The charts clearly show that an engine fuelled with AMEs causes the exhaust gas to have substantially fewer unburned 
hydrocarbons than in the case of DF. At $1400 \mathrm{rpm}$ and with the use of AMEs, the THC was $45.7 \%$ lower on average. At $2200 \mathrm{rpm}$ and with the use of AMEs, THC in the engine's exhaust gas was approximately $45.5 \%$ lower on average. Numerous tests of engines fuelled with various pure esters and mixtures of esters and DF have demonstrated a reduction in the concentrations of unburned hydrocarbons in the exhaust gas $[27,65,78,82,84,95]$. The high cetane number and oxygen content of esters causes combustion to take place at higher temperatures. This favours fuel burning and lowers the THC in the exhaust gas.
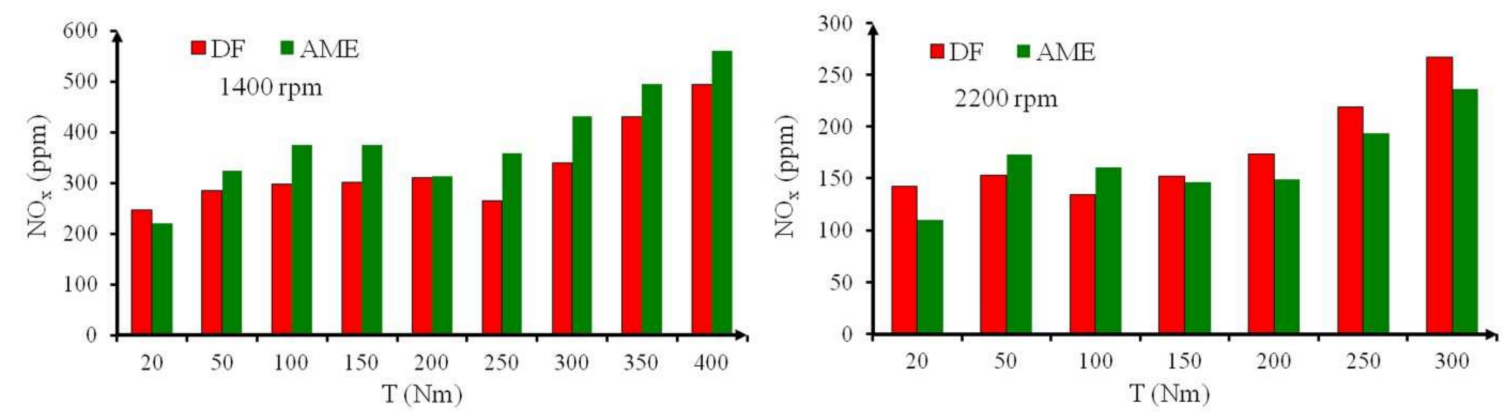

Figure 11. Comparison $\mathrm{NO}_{\mathrm{x}}$ concentrations in the exhaust gas of the engine fuelled with $\mathrm{AME}$ and $\mathrm{DF}$ and operating at a load specification of 1400 and $2200 \mathrm{rpm}$.
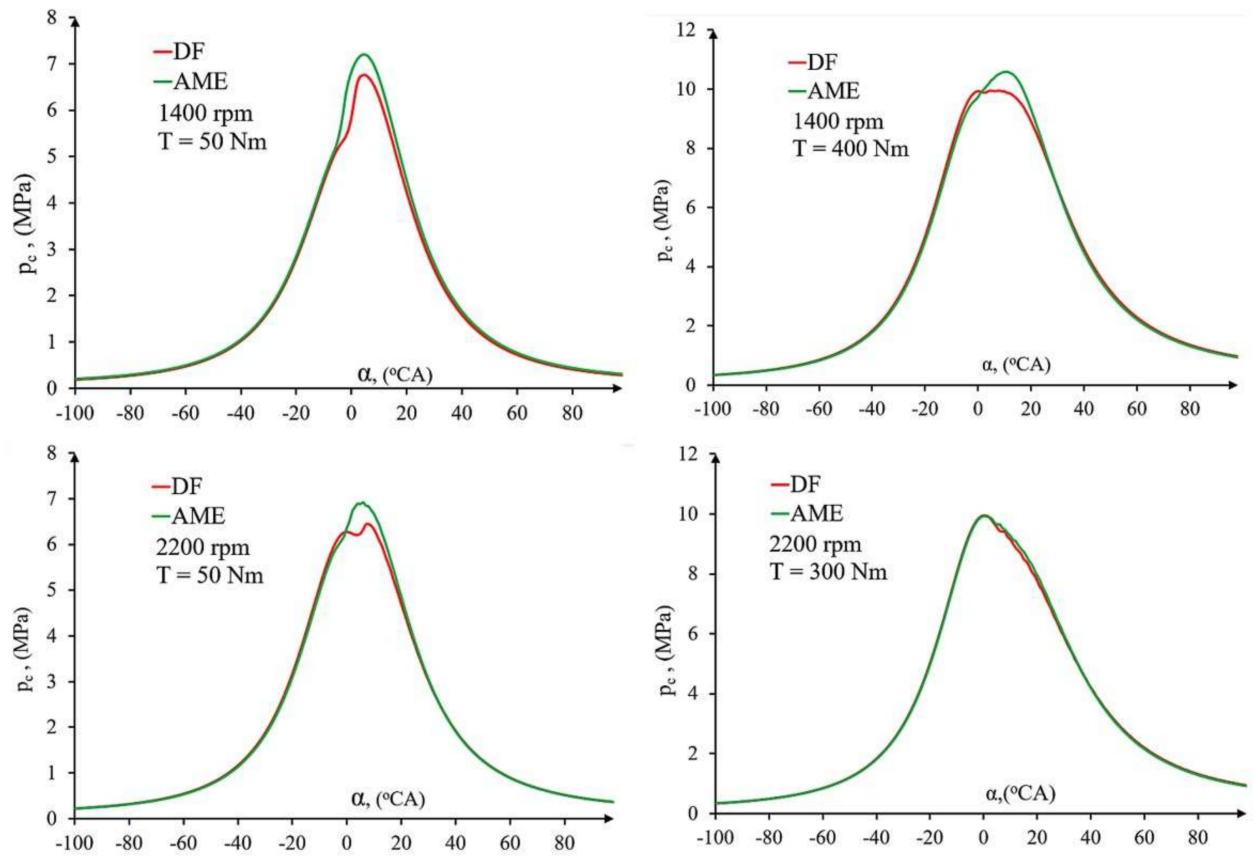

Figure 12. Comparison of engine cylinder pressure waveforms for the burning process with AME and DF fuelling.
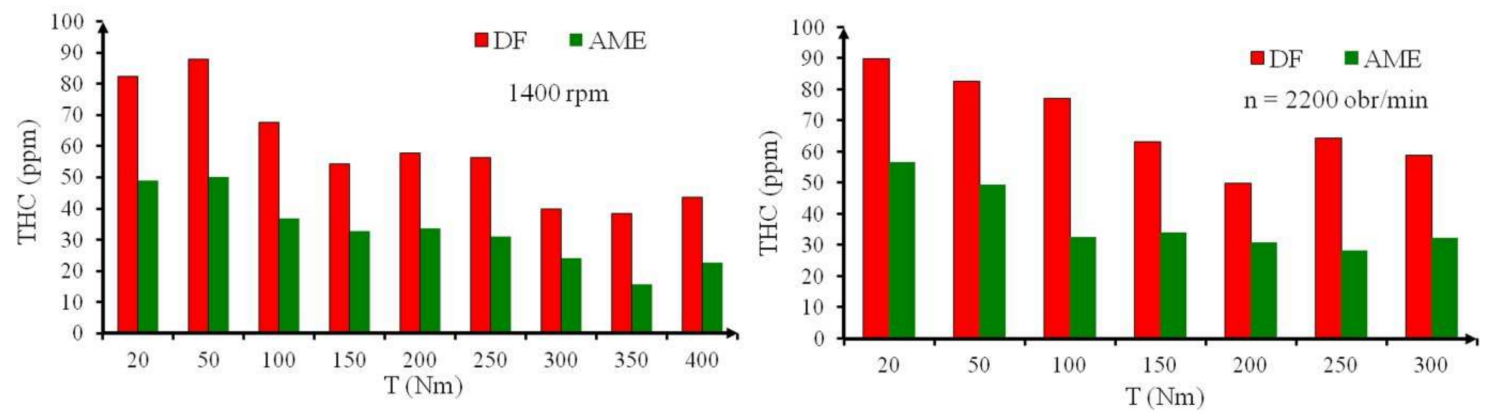

Figure 13. Comparison of THC concentrations in the exhaust gas of the engine fuelled with AME and DF and operating at a load specification of 1400 and $2200 \mathrm{rpm}$. 
The Mexa 1230PM analyser from Horiba measures soluble organic fractions, soot, and the total content of particulate matter in exhaust gas. Figure 14 presents a comparison of the soot content in the exhaust gas of the test engine fuelled with AMEs versus DF. For measurements conducted at $1400 \mathrm{rpm}$ and with AMEs, the average soot concentration was approximately $17.9 \%$ lower in comparison to DF. The average soot concentration in the exhaust gas of the engine operating at $2200 \mathrm{rpm}$ and fuelled with AMEs was 30\% lower. Lemaire et al. demonstrated that the addition of esters to DF causes the soot generated during combustion to oxidise more quickly [99]. The second component of particulate matter is the soluble organic fractions. The SOF concentrations in the exhaust gas of the engine fuelled with AMEs and with DF are presented in Figure 15. Substantially lower SOF concentrations were found for AME biodiesel than for DF. The average SOF concentrations for AMEs were $76.2 \%$ and $65.3 \%$ lower at $1400 \mathrm{rpm}$ and $2200 \mathrm{rpm}$, respectively. The comparison of PM concentrations in the exhaust gas of the Perkins 1104D-44TA engine fuelled with AMEs versus DF is presented in Figure 16. The PM concentration for AMEs was on average $36.5 \%$ and $39.7 \%$ lower in measurements conducted at 1400 and $2200 \mathrm{rpm}$, respectively, than that of DF. The lower PM concentrations for AME biodiesel in comparison with DF derive from the oxygen contained in the ester particles and the good self-ignition properties and higher temperatures of the combustion process. The authors of other studies have also demonstrated that the use of various esters causes a substantial reduction in PM concentrations in the exhaust gasses of diesel engines $[26,78,100,101]$. The authors of this paper demonstrated the same property for esters obtained from animal waste.

The smoke opacity of the engine exhaust gas does not provide information on the composition of the gas, but it does offer an indirect indication of the quality of the combustion process. This also depends on the type and properties of the fuel used. As presented in Figure 17, the use of AME biodiesel for fuelling the 1104D-44TA engine operating at a specified load of 1400 and $2200 \mathrm{rpm}$ led to a substantially lower smoke opacity of the exhaust gas in comparison with the smoke opacity of the engine fuelled with DF. With the AME biodiesel, the smoke opacity of the exhaust gas was on average $44.9 \%$ and $42.0 \%$ lower at 1400 and $2200 \mathrm{rpm}$, respectively. These results are correlated with the THC, SOF, soot, and total PM results. Other researchers have also demonstrated lower exhaust gas smoke opacity when fuelling an engine with esters [27,82].
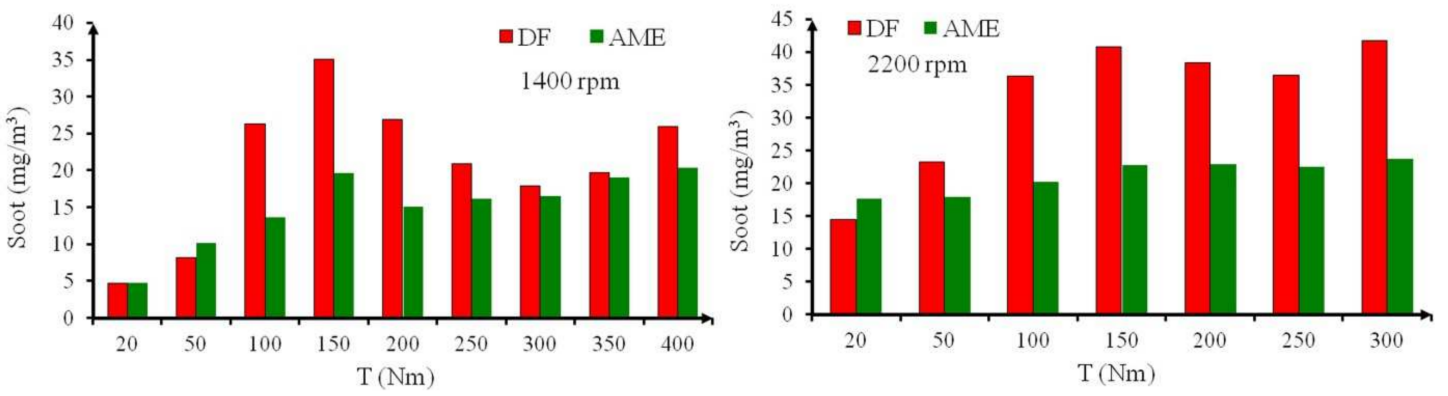

Figure 14. Comparison of soot concentrations in the exhaust gas of the engine fuelled with AME and DF and operating at a load specification of 1400 and $2200 \mathrm{rpm}$.
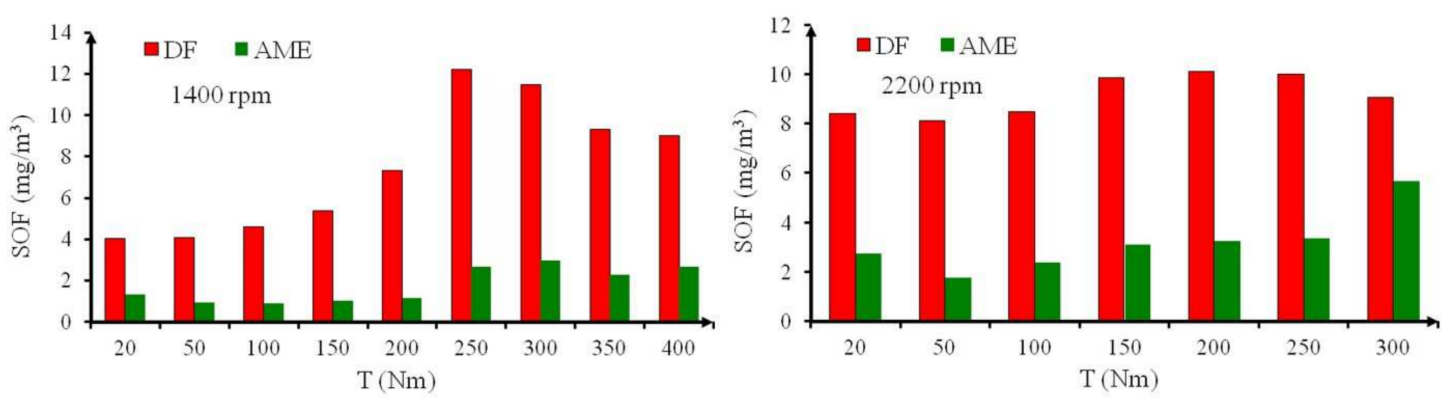

Figure 15. Comparison of SOF concentrations in the exhaust gas of the engine fuelled with AME and DF and operating at a load specification of 1400 and $2200 \mathrm{rpm}$. 

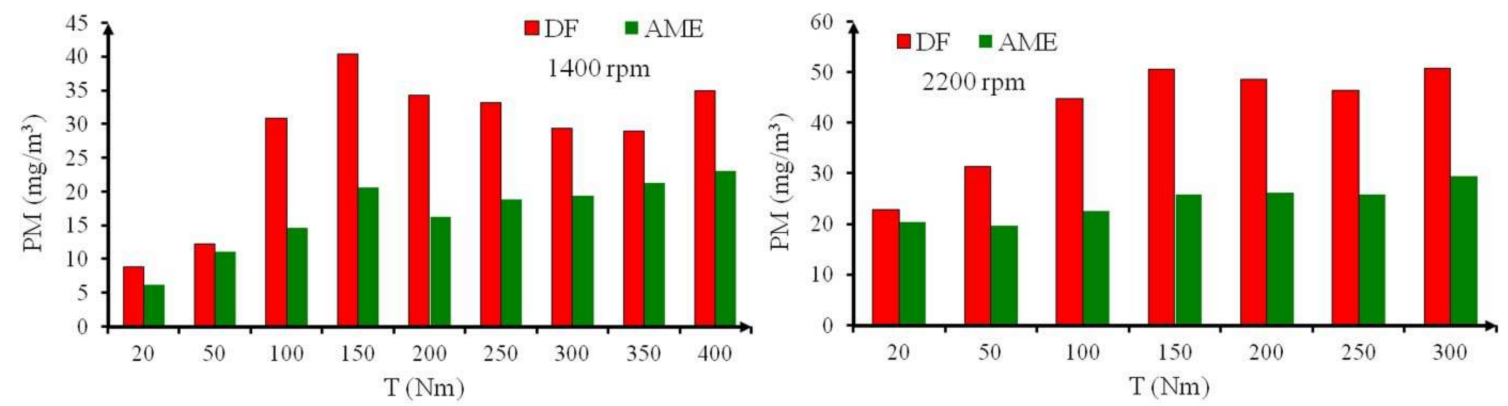

Figure 16. Comparison of PM concentrations in the exhaust gas of the engine fuelled with AME and DF and operating at a load specification of 1400 and $2200 \mathrm{rpm}$.
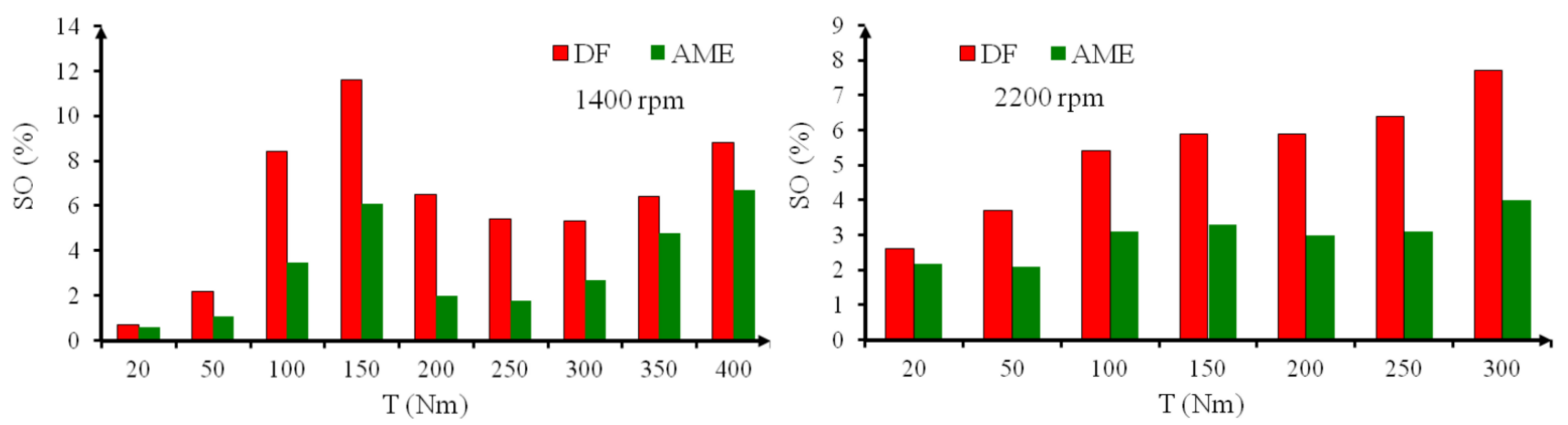

Figure 17. Comparison of the exhaust gas smoke opacity in the engine operating at a load specification of 1400 and 2200 rpm when fuelled with AME and DF.

Figure 18 presents the average relative changes in the analysed operating indicators of the Perkins 1104D-44TA engine fuelled with AMEs in comparison with those of the engine when fuelled with DF over the entire tested load range for 1400 and $2200 \mathrm{rpm}$. Most of the engine operating indicators were more favourable for AMEs than for DF.
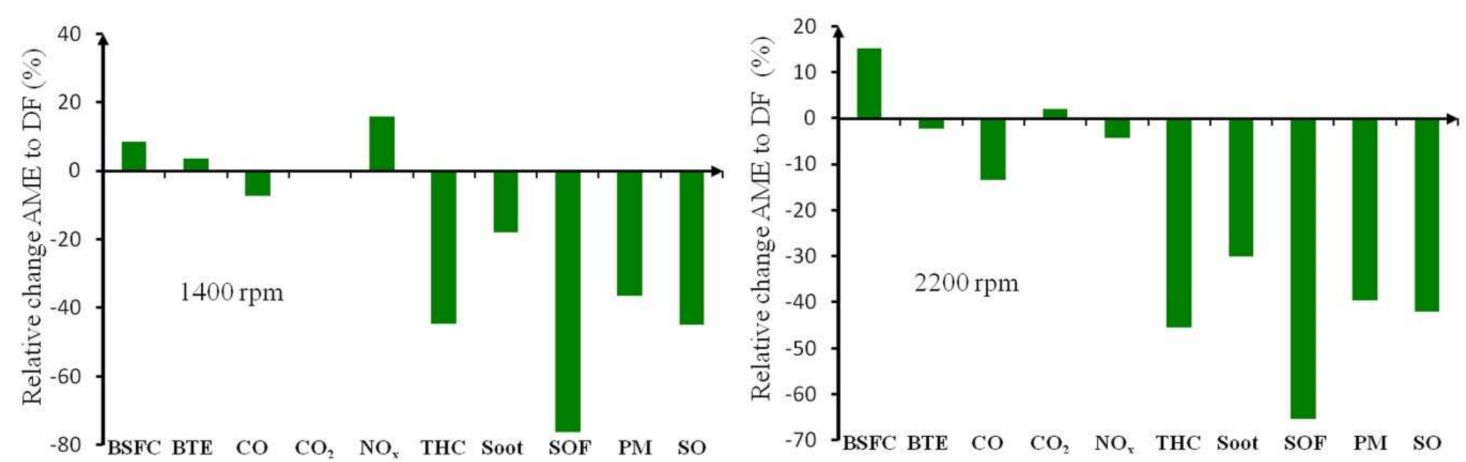

Figure 18. Average relative changes in the operating indicators of the engine fuelled with AME operating at a load specification of 1400 and $2200 \mathrm{rpm}$ in relation to DF over the entire tested load range for 1400 and $2200 \mathrm{rpm}$.

A measurement uncertainty analysis was conducted for the measured and calculated engine operating indicators. The formulae presented in Section 2.5 were used to calculate the standard uncertainties of the arithmetic means of the operating indicators, as well as the combined uncertainties of the calculated operating indicators of the Perkins 1104D-44TA engine fuelled with the two fuels. The results can be seen in Tables 6-9. 
Table 6. Standard uncertainties of the measured arithmetic means of the operating indicators and combined uncertainties of calculated operating indicators of the Perkins 1104D-44TA engine fuelled with AME and operating at $\mathrm{n}=1400 \mathrm{rpm}$.

\begin{tabular}{|c|c|c|c|c|c|c|c|c|c|c|c|c|c|}
\hline \multirow{2}{*}{$\begin{array}{c}\mathrm{T} \\
(\mathrm{Nm})\end{array}$} & \multicolumn{11}{|c|}{ Quantities Measured Directly } & \multicolumn{2}{|c|}{$\begin{array}{l}\text { Calculated } \\
\text { Quantities }\end{array}$} \\
\hline & $\begin{array}{c}\Delta \mathrm{CO} \\
(\mathrm{ppm})\end{array}$ & $\begin{array}{c}\Delta \mathrm{CO}_{2} \\
(\%)\end{array}$ & $\begin{array}{l}\Delta \mathrm{NO}_{\mathrm{x}} \\
(\mathrm{ppm})\end{array}$ & $\begin{array}{c}\Delta \mathrm{O}_{2} \\
(\%)\end{array}$ & $\begin{array}{r}\Delta \mathrm{THC} \\
(\mathrm{ppm})\end{array}$ & $\begin{array}{l}\Delta \text { Soot } \\
\left(\mathrm{mg} / \mathrm{m}^{3}\right)\end{array}$ & $\begin{array}{l}\Delta S O F \\
\left(\mathrm{mg} / \mathrm{m}^{3}\right)\end{array}$ & $\begin{array}{c}\Delta \mathrm{PM} \\
\left(\mathrm{mg} / \mathrm{m}^{3}\right)\end{array}$ & $\begin{array}{c}\Delta \mathrm{T} \\
(\mathrm{Nm})\end{array}$ & $\begin{array}{c}\Delta \mathbf{P} \\
(\mathbf{k W})\end{array}$ & $\begin{array}{c}\Delta \mathrm{FC} \\
(\mathrm{kg} / \mathrm{h})\end{array}$ & $\begin{array}{c}\Delta(\mathrm{BSFC})_{\mathrm{c}} \\
(\mathrm{g} / \mathrm{kWh})\end{array}$ & $\begin{array}{l}\Delta(\mathrm{BTE})_{\mathrm{c}} \\
\quad(\%)\end{array}$ \\
\hline 20 & 0.094 & 0.012 & 1.241 & 0.041 & 1.603 & 0.327 & 0.059 & 0.344 & 0.102 & 0.015 & 0.049 & 16.950 & 0.358 \\
\hline 50 & 0.071 & 0.013 & 1.448 & 0.023 & 0.486 & 0.212 & 0.015 & 0.212 & 0.101 & 0.015 & 0.009 & 1.449 & 0.093 \\
\hline 100 & 0.067 & 0.008 & 3.314 & 0.018 & 0.564 & 0.276 & 0.012 & 0.280 & 0.129 & 0.021 & 0.057 & 3.895 & 0.421 \\
\hline 150 & 0.112 & 0.011 & 2.582 & 0.020 & 0.307 & 0.741 & 0.088 & 0.716 & 0.129 & 0.021 & 0.028 & 1.297 & 0.178 \\
\hline 200 & 0.059 & 0.005 & 30.005 & 0.016 & 1.437 & 0.817 & 0.038 & 0.832 & 0.158 & 0.039 & 0.020 & 0.759 & 0.108 \\
\hline 250 & 0.075 & 0.000 & 1.410 & 0.020 & 0.414 & 0.375 & 0.207 & 0.461 & 0.202 & 0.047 & 0.039 & 1.109 & 0.173 \\
\hline 300 & 0.071 & 0.000 & 2.731 & 0.021 & 0.238 & 0.272 & 0.224 & 0.397 & 0.153 & 0.053 & 0.137 & 3.116 & 0.522 \\
\hline 350 & 0.086 & 0.000 & 2.053 & 0.015 & 1.511 & 0.605 & 0.055 & 0.588 & 0.175 & 0.049 & 0.197 & 3.843 & 0.649 \\
\hline 400 & 0.122 & 0.000 & 3.453 & 0.023 & 0.315 & 0.688 & 0.050 & 0.659 & 0.263 & 0.091 & 0.053 & 0.972 & 0.167 \\
\hline
\end{tabular}

Table 7. Standard uncertainties of the measured arithmetic means of the operating indicators and combined uncertainties of calculated operating indicators of the Perkins 1104D-44TA engine fuelled with AME and operating at $\mathrm{n}=2200 \mathrm{rpm}$.

\begin{tabular}{|c|c|c|c|c|c|c|c|c|c|c|c|c|c|}
\hline \multirow{2}{*}{$\begin{array}{c}\mathrm{T} \\
(\mathrm{Nm})\end{array}$} & \multicolumn{11}{|c|}{ Quantities Measured Directly } & \multicolumn{2}{|c|}{$\begin{array}{l}\text { Calculated } \\
\text { Quantities }\end{array}$} \\
\hline & $\begin{array}{c}\Delta \mathrm{CO} \\
(\mathrm{ppm})\end{array}$ & $\begin{array}{c}\Delta \mathrm{CO}_{2} \\
(\%)\end{array}$ & $\begin{array}{l}\Delta \mathrm{NO}_{\mathrm{x}} \\
(\mathrm{ppm})\end{array}$ & $\begin{array}{c}\Delta \mathrm{O}_{2} \\
(\%)\end{array}$ & $\begin{array}{l}\Delta \mathrm{THC} \\
(\mathrm{ppm})\end{array}$ & $\begin{array}{l}\Delta \text { Soot } \\
\left(\mathrm{mg} / \mathrm{m}^{3}\right)\end{array}$ & $\begin{array}{l}\Delta S O F \\
\left(\mathrm{mg} / \mathrm{m}^{3}\right)\end{array}$ & $\begin{array}{c}\Delta \mathrm{PM} \\
\left(\mathrm{mg} / \mathrm{m}^{3}\right)\end{array}$ & $\begin{array}{c}\Delta \mathrm{T} \\
(\mathrm{Nm})\end{array}$ & $\begin{array}{c}\Delta \mathbf{P} \\
(\mathbf{k W})\end{array}$ & $\begin{array}{c}\Delta \mathrm{FC} \\
(\mathrm{kg} / \mathrm{h})\end{array}$ & $\begin{array}{l}\Delta(\mathrm{BSFC})_{\mathrm{c}} \\
(\mathrm{g} / \mathrm{kWh})\end{array}$ & $\begin{array}{l}\Delta(\mathrm{BTE})_{\mathrm{C}} \\
\quad(\%)\end{array}$ \\
\hline 20 & 0.043 & 0.011 & 0.621 & 0.058 & 1.215 & 0.335 & 0.227 & 0.499 & 0.108 & 0.025 & 0.018 & 6.079 & 0.073 \\
\hline 50 & 0.108 & 0.028 & 0.597 & 0.069 & 0.901 & 0.235 & 0.037 & 0.244 & 0.106 & 0.024 & 0.016 & 1.640 & 0.085 \\
\hline 100 & 0.047 & 0.026 & 1.526 & 0.024 & 0.614 & 0.316 & 0.141 & 0.421 & 0.123 & 0.028 & 0.023 & 1.091 & 0.091 \\
\hline 150 & 0.048 & 0.017 & 2.997 & 0.038 & 0.393 & 0.334 & 0.132 & 0.447 & 0.177 & 0.040 & 0.034 & 1.045 & 0.106 \\
\hline 200 & 0.050 & 0.007 & 1.809 & 0.012 & 0.275 & 0.229 & 0.064 & 0.223 & 0.119 & 0.030 & 0.034 & 0.762 & 0.081 \\
\hline 250 & 0.000 & 0.005 & 2.527 & 0.012 & 0.407 & 0.834 & 0.108 & 0.863 & 0.145 & 0.033 & 0.197 & 3.422 & 0.328 \\
\hline 300 & 0.048 & 0.000 & 1.588 & 0.018 & 1.067 & 1.053 & 1.408 & 1.179 & 0.153 & 0.062 & 0.057 & 0.860 & 0.113 \\
\hline
\end{tabular}

Table 8. Standard uncertainties of the measured arithmetic means of the operating indicators and combined uncertainties of calculated operating indicators of the Perkins 1104D-44TA engine fuelled with DF and operating at $\mathrm{n}=1400 \mathrm{rpm}$.

\begin{tabular}{|c|c|c|c|c|c|c|c|c|c|c|c|c|c|}
\hline \multirow{2}{*}{$\begin{array}{c}\mathrm{T} \\
(\mathrm{Nm})\end{array}$} & \multicolumn{11}{|c|}{ Quantities Measured Directly } & \multicolumn{2}{|c|}{$\begin{array}{l}\text { Calculated } \\
\text { Quantities }\end{array}$} \\
\hline & $\begin{array}{c}\Delta \mathrm{CO} \\
(\mathrm{ppm})\end{array}$ & $\begin{array}{c}\Delta \mathrm{CO}_{2} \\
(\%)\end{array}$ & $\begin{array}{l}\Delta \mathrm{NO}_{\mathrm{x}} \\
\text { (ppm) }\end{array}$ & $\begin{array}{c}\Delta \mathrm{O}_{2} \\
(\%)\end{array}$ & $\begin{array}{l}\Delta \mathrm{THC} \\
(\mathrm{ppm})\end{array}$ & $\begin{array}{l}\Delta \text { Soot } \\
\left(\mathrm{mg} / \mathrm{m}^{3}\right)\end{array}$ & $\begin{array}{l}\Delta S O F \\
\left(\mathrm{mg} / \mathrm{m}^{3}\right)\end{array}$ & $\begin{array}{c}\Delta \mathrm{PM} \\
\left(\mathrm{mg} / \mathrm{m}^{3}\right)\end{array}$ & $\begin{array}{c}\Delta \mathrm{T} \\
(\mathrm{Nm})\end{array}$ & $\begin{array}{c}\Delta P \\
(\mathbf{k W})\end{array}$ & $\begin{array}{c}\Delta \mathrm{FC} \\
(\mathrm{kg} / \mathrm{h})\end{array}$ & $\begin{array}{c}\Delta(\mathrm{BSFC})_{\mathrm{c}} \\
(\mathrm{g} / \mathrm{kWh})\end{array}$ & $\begin{array}{c}\Delta(\mathrm{BTE})_{\mathrm{C}} \\
(\%)\end{array}$ \\
\hline 20 & 0.037 & 0.011 & 1.149 & 0.033 & 1.735 & 0.102 & 0.437 & 0.477 & 0.079 & 0.012 & 0.014 & 5.537 & 0.107 \\
\hline 50 & 0.055 & 0.007 & 2.121 & 0.165 & 1.387 & 0.371 & 0.363 & 0.649 & 0.173 & 0.025 & 0.075 & 10.311 & 0.744 \\
\hline 100 & 0.057 & 0.008 & 2.069 & 0.469 & 1.644 & 1.132 & 0.341 & 1.304 & 0.118 & 0.018 & 0.110 & 7.490 & 0.901 \\
\hline 150 & 0.071 & 0.011 & 2.052 & 0.329 & 1.961 & 1.320 & 0.301 & 1.416 & 0.180 & 0.024 & 0.367 & 16.669 & 2.327 \\
\hline 200 & 0.083 & 0.005 & 1.604 & 0.227 & 2.046 & 1.580 & 0.313 & 1.689 & 0.122 & 0.020 & 0.070 & 2.395 & 0.388 \\
\hline 250 & 0.078 & 0.005 & 1.748 & 0.216 & 2.592 & 1.518 & 1.307 & 1.627 & 0.137 & 0.025 & 0.315 & 8.589 & 1.197 \\
\hline 300 & 0.030 & 0.011 & 1.412 & 0.021 & 0.801 & 1.106 & 0.396 & 1.166 & 0.130 & 0.031 & 0.076 & 1.737 & 0.301 \\
\hline 350 & 0.058 & 0.008 & 2.356 & 0.353 & 0.493 & 0.894 & 0.261 & 0.941 & 0.177 & 0.059 & 0.253 & 4.932 & 0.869 \\
\hline 400 & 0.065 & 0.004 & 1.933 & 0.245 & 0.908 & 1.084 & 0.177 & 1.085 & 0.180 & 0.058 & 0.143 & 2.444 & 0.492 \\
\hline
\end{tabular}

Table 9. Standard uncertainties of the measured arithmetic means of the operating indicators and combined uncertainties of calculated operating indicators of the Perkins 1104D-44TA engine fuelled with DF and operating at $\mathrm{n}=2200 \mathrm{rpm}$.

\begin{tabular}{|c|c|c|c|c|c|c|c|c|c|c|c|c|c|}
\hline \multirow{2}{*}{$\begin{array}{c}\mathrm{T} \\
(\mathrm{Nm})\end{array}$} & \multicolumn{11}{|c|}{ Quantities Measured Directly } & \multicolumn{2}{|c|}{$\begin{array}{l}\text { Calculated } \\
\text { Quantities }\end{array}$} \\
\hline & $\begin{array}{c}\Delta \mathrm{CO} \\
(\mathrm{ppm})\end{array}$ & $\begin{array}{c}\Delta \mathrm{CO}_{2} \\
(\%)\end{array}$ & $\begin{array}{l}\Delta \mathrm{NO}_{\mathrm{x}} \\
(\mathrm{ppm})\end{array}$ & $\begin{array}{c}\Delta \mathrm{O}_{2} \\
(\%)\end{array}$ & $\begin{array}{l}\Delta \mathrm{THC} \\
(\mathrm{ppm})\end{array}$ & $\begin{array}{l}\Delta \text { Soot } \\
\left(\mathrm{mg} / \mathrm{m}^{3}\right)\end{array}$ & $\begin{array}{l}\Delta S O F \\
\left(\mathrm{mg} / \mathrm{m}^{3}\right)\end{array}$ & $\begin{array}{c}\Delta \mathrm{PM} \\
\left(\mathrm{mg} / \mathrm{m}^{3}\right)\end{array}$ & $\begin{array}{c}\Delta \mathrm{T} \\
(\mathrm{Nm})\end{array}$ & $\begin{array}{c}\Delta P \\
(\mathbf{k W})\end{array}$ & $\begin{array}{c}\Delta \mathrm{FC} \\
(\mathrm{kg} / \mathrm{h})\end{array}$ & $\begin{array}{l}\Delta(\mathrm{BSFC})_{\mathrm{c}} \\
(\mathrm{g} / \mathrm{kWh})\end{array}$ & $\begin{array}{l}\Delta(\mathrm{BTE})_{\mathrm{c}} \\
\quad(\%)\end{array}$ \\
\hline 20 & 0.107 & 0.024 & 0.575 & 0.043 & 3.627 & 0.419 & 1.061 & 1.308 & 0.130 & 0.030 & 0.023 & 7.031 & 0.071 \\
\hline 50 & 0.040 & 0.007 & 1.212 & 0.597 & 1.674 & 0.486 & 0.473 & 0.638 & 0.113 & 0.027 & 0.025 & 2.352 & 0.109 \\
\hline 100 & 0.076 & 0.018 & 0.751 & 0.083 & 1.461 & 0.685 & 1.073 & 0.971 & 0.128 & 0.031 & 0.028 & 1.272 & 0.116 \\
\hline 150 & 0.057 & 0.024 & 0.620 & 0.377 & 1.607 & 1.100 & 0.640 & 1.266 & 0.093 & 0.024 & 0.105 & 3.036 & 0.358 \\
\hline 200 & 0.041 & 0.018 & 0.780 & 0.117 & 1.227 & 0.705 & 0.391 & 0.841 & 0.118 & 0.027 & 0.114 & 2.473 & 0.307 \\
\hline 250 & 0.021 & 0.005 & 0.819 & 0.016 & 0.786 & 1.355 & 1.044 & 2.039 & 0.124 & 0.031 & 0.049 & 0.859 & 0.128 \\
\hline 300 & 0.050 & 0.001 & 0.743 & 0.018 & 1.177 & 1.192 & 0.606 & 1.360 & 0.137 & 0.044 & 0.330 & 4.789 & 0.729 \\
\hline
\end{tabular}




\section{Conclusions}

Increasing attention is currently being paid to reducing the harmful impact of diesel engines on the environment. One possibility is to use biofuels, as they constitute a renewable energy source. New-generation biofuels, whose use will not impact food prices, are currently being sought after.

The tests presented in this paper covered esters obtained from animal fat waste. The authors produced animal fat methyl esters derived from waste generated in the animal hide processing industry. The esters were produced in a reactor intended for non-industrial ester production. The resulting fuel can be classified as a second-generation biofuel. The production of fuel from such raw materials allows for the utilisation of residual waste.

The test results demonstrated that it is possible to fuel a diesel engine with pure animal fatty acid esters. It was, however, necessary to ensure adequate liquidity of these esters during testing, which was achieved by heating the esters in a tank. During normal engine use, it would be necessary to supplement this fuel with additives in order to lower the cloud point and cold filter plugging point. No problems with the engine's operation were encountered during testing; the engine operated correctly under the test conditions.

The tests of the engine fuelled with AME biodiesel demonstrated the fuel's favourable features in terms of reducing the engine's impact on the environment. The primary conclusions drawn from the tests are as follows:

- The use of pure AMEs to fuel the engine allowed for a substantial reduction in the hydrocarbon and PM concentrations of the exhaust gas when compared to DF. The average reduction in THC concentration of the exhaust gas over the entire load range investigated was approximately $45 \%$ lower, whereas the average reduction in PM concentration was approximately $36.5 \%$ lower at $1400 \mathrm{rpm}$ and $39.7 \%$ lower at $2200 \mathrm{rpm}$.

- Fuelling the engine with AMEs also led to the average reduction in smoke opacity that was over $40 \%$ lower over the entire load range investigated both for $1400 \mathrm{rpm}$ and $2200 \mathrm{rpm}$.

- The $\mathrm{CO}_{2}$ concentrations of the exhaust gas were comparable for the two fuels.

- Fuelling the engine with AMEs resulted in the average reduction in $\mathrm{CO}$ concentration that was approximately $7.2 \%$ at $1400 \mathrm{rpm}$ and $13.4 \%$ at $2200 \mathrm{rpm}$ over the entire load range investigated.

- Fuel consumption increased with the use of the AME fuel. The average increased BSFC over the entire load range investigated amounted to approximately $8.4 \%$ at $1400 \mathrm{rpm}$ and $15.2 \%$ at $2200 \mathrm{rpm}$. This is obviously a result of the biodiesel's lower heating value.

- The average increased in $\mathrm{NO}_{\mathrm{x}}$ concentrations of the exhaust gas amounted to approximately $15.9 \%$ over the entire load range investigated for $1400 \mathrm{rpm}$ when the engine was fuelled with AMEs. On the other hand, at $2200 \mathrm{rpm}$, the average reduction in $\mathrm{NO}_{\mathrm{x}}$ concentration amounted to approximately $4.4 \%$ when the engine was fuelled with AMEs. It can be assumed that with suitable fuel injection control, it is possible to reduce $\mathrm{NO}_{\mathrm{x}}$ emissions at lower crankshaft rotation speeds. This aspect requires further research.

- Similar BTE quantities were obtained when the engine was fuelled with AMEs and with DF. AME fuel is characterised by high self-ignition capabilities. A correction in the injection process may improve the effectiveness of the combustion process. Further detailed testing would be required for this purpose.

When the engine was fuelled with AMEs, its negative environmental impact was reduced. Similar indicators were achieved when engines were fuelled with esters obtained from vegetable fatty acids [88]. The raw material for AME production is cheaper, as it is waste that must otherwise be disposed of. Producing fuel from this waste is one way of solving this problem.

It is necessary to carry out further research on AME esters obtained from waste fat extracted from hides of animals prior to the tanning process. The tests should focus on a 
detailed analysis of the combustion process in order to optimize the operation parameters of the engine fuelled with AME biodiesel. Another important research issue would be improvement of the fuel properties under low temperatures. In addition, reliability tests of the AME- powered engine should be conducted.

Author Contributions: Conceptualization, D.K. and G.W.; methodology, D.K. and G.W.; software, D.K., G.W. and P.Ł.; validation, D.K., G.W. and P.Ł.; formal analysis, D.K.; investigation, D.K., G.W. and P.Ł.; resources, D.K. GW and P.Ł.; data curation, D.K., G.W. and P.Ł.; writing-original draft preparation, D.K.; writing-review and editing, D.K.; visualization, D.K., G.W. and P.Ł.; supervision, D.K.; project administration, D.K.; funding acquisition, D.K. All authors have read and agreed to the published version of the manuscript.

Funding: This research was funded by the Faculty of Mechatronics and Mechanical Engineering, Kielce University of Technology and the Faculty of Production Engineering and Power Technologies, University of Agriculture in Krakow.

Data Availability Statement: The data presented in this study are available from the corresponding author on reasonable request.

Acknowledgments: The authors gratefully acknowledge the Faculty of Mechatronics and Mechanical Engineering, Kielce University of Technology and the "BioEnergia" Małopolskie Centre for Renewable Energy Sources.

Conflicts of Interest: The authors declare no conflict of interest.

\section{Nomenclature}

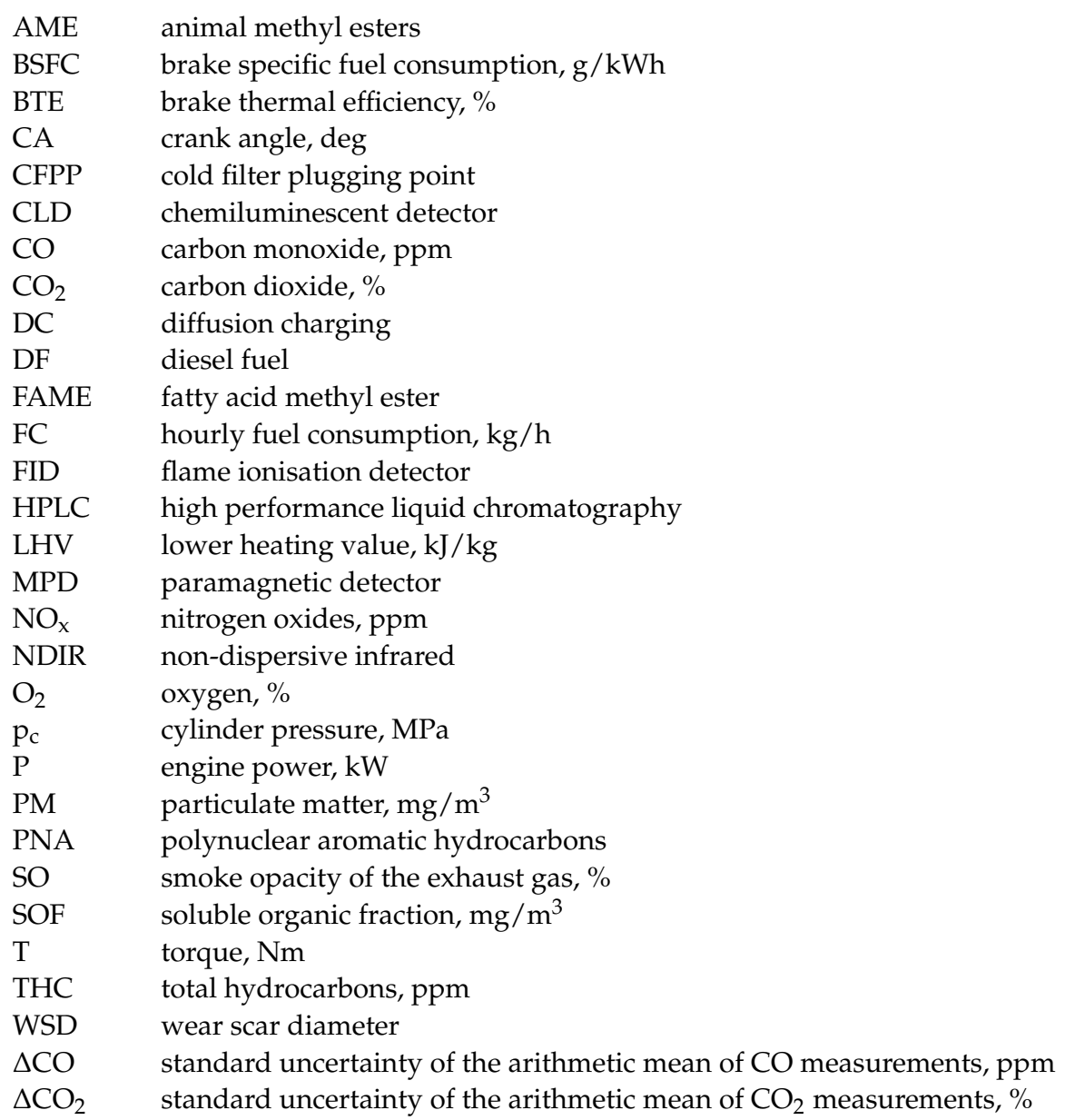


$\Delta \mathrm{NO}_{\mathrm{x}} \quad$ standard uncertainty of the arithmetic mean of $\mathrm{NO}_{\mathrm{x}}$ measurements, ppm

$\Delta \mathrm{O}_{2} \quad$ standard uncertainty of the arithmetic mean of $\mathrm{O}_{2}$ measurements, $\%$

$\triangle T H C \quad$ standard uncertainty of the arithmetic mean of THC measurements, ppm

$\Delta$ Soot standard uncertainty of the arithmetic mean of Soot measurements, $\mathrm{mg} / \mathrm{m}^{3}$

$\triangle \mathrm{SOF} \quad$ standard uncertainty of the arithmetic mean of SOF measurements, $\mathrm{mg} / \mathrm{m}^{3}$

$\triangle \mathrm{PM} \quad$ standard uncertainty of the arithmetic mean of PM measurements, $\mathrm{mg} / \mathrm{m}^{3}$

$\Delta \mathrm{T} \quad$ standard uncertainty of the arithmetic mean of T measurements, $\mathrm{Nm}$

$\Delta \mathrm{P} \quad$ standard uncertainty of the arithmetic mean of $\mathrm{P}$ measurements, $\mathrm{kW}$

$\triangle F C \quad$ standard uncertainty of the arithmetic mean of FC measurements, $\mathrm{kg} / \mathrm{h}$

$\triangle(\text { BSFC })_{C} \quad$ complex uncertainty of BSFC calculations, $\mathrm{g} / \mathrm{kWh}$

$\Delta(\mathrm{BTE})_{\mathrm{C}} \quad$ complex uncertainty of BTE calculations, $\%$

\section{References}

1. Klimiuk, E.; Pawłowska, M.; Pokój, T. Biofuels. Technologies for Sustainable Development; Polish Scientific Publishers PWN: Warsaw, Poland, 2012.

2. Tayari, S.; Abedi, R.; Rahi, A. Comparative assessment of engine performance and emissions fueled with three different biodiesel generations. Renew. Energy 2020, 147, 1058-1069. [CrossRef]

3. Bhuiya, M.M.K.; Rasul, M.G.; Khan, M.M.K.; Ashwath, N.; Azad, A.K. Prospects of 2nd generation biodiesel as a sustainable fuel-Part: 1 selection of feedstocks, oil extraction techniques and conversion technologies. Renew. Sustain. Energy Rev. 2016, 55, 1109-1128. [CrossRef]

4. Naik, S.N.; Goud, V.V.; Rout, P.K.; Dalai, A.K. Production of first and second generation biofuels: A comprehensive review. Renew. Sustain. Energy Rev. 2010, 14, 578-597. [CrossRef]

5. Yaşar, F. Comparison of fuel properties of biodiesel fuels produced from different oils $\mathrm{T}_{\mathrm{T}}$ to determine the most suitable feedstock type. Fuel 2020, 264, 116817. [CrossRef]

6. Yesilyurt, M.K. The examination of a compression-ignition engine powered by peanut oil biodiesel and diesel fuel in terms of energetic and exegetic performance parameters. Fuel 2020, 278, 118319. [CrossRef]

7. Saravanan, A.; Murugan, M.; Sreenivasa, R.M.; Parida, S. Performance and emission characteristics of variable compression ratio CI engine fueled with dual biodiesel blends of Rapeseed and Mahua. Fuel 2020, 263, 116751. [CrossRef]

8. Zhong, W.; Xuan, T.; He, Z.; Wang, Q.; Li, D.; Zhang, X.; Yin, H.Y. Experimental study of combustion and emission characteristics of diesel engine with diesel/second-generation biodiesel blending fuels. Energy Convers. Manag. 2016, 121, 241-250. [CrossRef]

9. Singh, D.; Sharma, D.; Soni, S.L.; Sharma, S.; Kumari, D. Chemical compositions, properties, and standards for different generation biodiesels: A review. Fuel 2019, 253, 60-71. [CrossRef]

10. Saladini, F.; Patrizi, N.; Pulselli, F.M.; Marchettini, N.; Bastianoni, S. Guidelines for energy evaluation of first, second and third generation biofuels. Renew. Sustain. Energy Rev. 2016, 66, 221-227. [CrossRef]

11. Sakthivel, R.; Ramesh, K.; Purnachandran, R.; Shameer, P.M. A review on the properties, performance and emission aspects of the third generation biodiesels. Renew. Sustain. Energy Rev. 2018, 82, 2970-2992. [CrossRef]

12. Biernat, K. Perspectives for global development of biofuel technologies to 2050. Chemik 2012, 66, 1178-1189.

13. Damartzis, T.; Zabaniotou, A. Thermochemical conversion of biomass to second generation biofuels through integrated process design-A review. Renew. Sustain. Energy Rev. 2011, 15, 366-378. [CrossRef]

14. Ghasemi, A.; Moosavi-Nasab, M. Production of second-generation biodiesel using low-quality date fruits. Biotechnol. Rep. 2020, 27, e00480. [CrossRef] [PubMed]

15. Singh, D.; Sharma, D.; Soni, S.L.; Sharma, S.; Sharma, P.K.; Jhalani, A. A review on feedstocks, production processes, and yield for different generations of biodiesel. Fuel 2020, 262, 116553. [CrossRef]

16. Commission of the European Communities. White Paper, European Transport Policy for 2010: Time to Decide; Commission of the European Communities: Brussels, Belgium, 2001.

17. Commission of the European Communities. Communication from the Commission, an EU Strategy for Biofuels; Commission of the European Communities: Brussels, Belgium, 2006.

18. Communication from the Commission to the Council and the European Parliament. Renewable Energy Road Map Renewable Energies in the 21st Century: Building a More Sustainable Future; Commission of the European Communities: Brussels, Belgium, 2007.

19. Commission of the European Communities. Communication from the Commission to the Council and the European Parliament. Final Report on the Green Paper "Towards a European Strategy for the Security of Energy Supply"; Commission of the European Communities: Brussels, Belgium, 2002.

20. European Parliament, Council of the European Union. Directive 2009/28/EC of the European Parliament and of the Council of 23 April 2009 on the Promotion of the Use of Energy from Renewable Sources and Amending and Subsequently Repealing Directives 2001/77/EC and 2003/30/EC; European Parliament: Strasbourg, France, 2009.

21. European Commission. Communication from the Commission to the European Parliament, the Council, the European Economic and Social Committee and the Committee of the Regions. In Clean Power for Transport: A European Alternative Fuels Strategy; European Commission: Brussels, Belgium. 
22. Kurczyński, D.; Łagowski, P. Performance indices of a common rail-system CI engine powered by diesel oil and biofuel blends. J. Energy Inst. 2019, 92, 1897-1913. [CrossRef]

23. Özener, O.; Yuksek, L.; Ergenc, A.T.; Ozkan, M. Effects of soybean biodiesel on a DI diesel engine performance, emission and combustion characteristics. Fuel 2014, 115, 875-883. [CrossRef]

24. Shehata, M.S.; Razak, S.M.A. Experimental investigation of diesel engine performance and emission characteristics using jojoba/diesel blend and sunflower oil. Fuel 2011, 90, 886-897. [CrossRef]

25. Aldhaidhawi, M.; Chiriac, R.; Badescu, V. Ignition delay, combustion and emission characteristics of Diesel engine fueled with rapeseed biodiesel-A literature review. Renew. Sustain. Energy Rev. 2017, 73, 178-186. [CrossRef]

26. Merkisz, J.; Kozak, M.; Pielecha, J.; Andrzejewski, M. The influence of application of different diesel fuel-RME blends on PM emissions from a diesel engine. Combust. Engines 2012, 1, 35-39.

27. Millo, F.; Debnath, B.K.; Vlachos, T.; Ciaravino, C.; Postrioti, L.; Buitoni, G. Effects of different biofuels blends on performance and emissions of an automotive diesel engine. Fuel 2015, 159, 614-627. [CrossRef]

28. Buyukkaya, E. Effects of biodiesel on a DI diesel engine performance, emission and combustion characteristics. Fuel 2010, 89, 3099-3105. [CrossRef]

29. Gad, M.S.; El-Araby, R.; Abed, K.A.; El-Ibiari, N.N.; El Morsi, A.K.; El-Diwani, G.I. Performance and emissions characteristics of C.I. engine fueled with palm oil/palm oil methyl ester blended with diesel fuel. Egypt. J. Petroleum 2018, 27, 215-219. [CrossRef]

30. Ilkiliç, C. The Effect of Sunflower Oil Methyl Ester and Diesel Fuel Blend on the Performance of a Diesel Engine. Energy Sources, Part A Recover. Util. Environ. Eff. 2008, 30, 1761-1770. [CrossRef]

31. Demirbas, A. Potential resources of non-edible oils for biodiesel. Energy Source Part B 2009, 4, 310-314. [CrossRef]

32. Balat, M. Potential alternatives to edible oils for biodiesel production-A review of current work. Energy Convers. Manag. 2011, 52, 1479-1492. [CrossRef]

33. Deepanraj, B.; Srinivas, M.; Arun, N.; Sankaranarayanan, G.; Abdul, S.P. Comparison of jatropha and karanja biofuels on their combustion characteristics. Int. J. Green Energy 2017, 14, 231-1237. [CrossRef]

34. Dhar, A.; Agarwal, A.K. Experimental investigations of the effect of pilot injection on performance, emissions and combustion characteristics of Karanja biodiesel fuelled CRDI engine. Energy Convers. Manag. 2015, 93, 357-366. [CrossRef]

35. Yadav, A.K.; Khan, M.E.; Dubey, A.M.; Pal, A. Performance and emission characteristics of a transportation diesel engine operated with non-edible vegetable oils biodiesel. Case Stud. Therm. Eng. 2016, 8, 236-244. [CrossRef]

36. Raheman, H.; Ghadge, S.V. Performance of compression ignition engine with mahua (Madhuca Indica) biodiesel. Fuel 2007, 86, 2568-2573. [CrossRef]

37. Ramadhas, A.S.; Jayaraj, S.; Muraleedharan, C. Biodiesel production from high FFA rubber seed oil. Fuel 2005, 84, 335-340. [CrossRef]

38. Ghadge, S.V.; Raheman, H. Biodiesel production from mahua (Madhuca Indica) oil having high free fatty acids. Biomass Bioenergy 2005, 28, 601-605. [CrossRef]

39. Veljković, V.B.; Lakicević, S.H.; Stamenković, O.S.; Todorović, Z.B.; Lazić, M.L. Biodiesel production from tobacco (Nicotianatabacum L.) seed oil with a high content of free fatty acids. Fuel 2006, 85, 2671-2675. [CrossRef]

40. Agarwal, A.K.; Rajamanoharan, K. Experimental investigations of performance and emissions of Karanja oil and its blends in a single cylinder agricultural diesel engine. Appl. Energy 2009, 86, 106-112. [CrossRef]

41. Ganapathy, T.; Murugesan, K.; Gakkhar, R.P. Performance optimization of Jatropha biodiesel engine model using Taguchi approach. Appl. Energy 2009, 86, 2476-2486. [CrossRef]

42. Huang, G.; Chen, F.; Wei, D.; Zhang, X.; Chen, G. Biodiesel production by microalgal biotechnology. Appl. Energy 2010, 87, 38-46. [CrossRef]

43. Akubude, V.C.; Nwaigwe, K.N.; Dintwa, E. Production of biodiesel from microalgae via nanocatalyzed transesterification process: A review. Mater. Sci. Energy Technol. 2019, 2, 216-225. [CrossRef]

44. Rajak, U.; Nashine, P.; Verma, T.N. Assessment of diesel engine performance using spirulina microalgae biodiesel. Energy 2019, 166, 1025-1036. [CrossRef]

45. Sun, J.; Xiong, X.; Wang, M.; Du, H.; Li, J.; Zhou, D.; Zuo, J. Microalgae biodiesel production in China: A preliminary economic analysis. Renew. Sustain. Energy Rev. 2019, 104, 296-306. [CrossRef]

46. Chen, J.; Li, J.; Dong, W.; Zhang, X.; Tyagi, R.D.; Drogui, P.; Surampalli, R.Y. The potential of microalgae in biodiesel production. Renew. Sustain. Energy Rev. 2018, 90, 336-346. [CrossRef]

47. Brennan, L.; Owende, P. Biofuels from microalgae-A review of technologies for production, processing, and extractions of biofuels and co-products. Renew. Sustain. Energy Rev. 2010, 14, 557-577. [CrossRef]

48. Christi, Y. Biodiesel from microalgae. Biotechnol. Adv. 2007, 25, 294-306. [CrossRef]

49. Faried, M.; Samer, M.; Abdelsalam, E.; Yousef, R.S.; Attia, Y.A.; Ali, A.S. Biodiesel production from microalgae: Processes, technologies and recent advancements. Renew. Sustain. Energy Rev. 2017, 79, 893-913. [CrossRef]

50. Brémond, U.; Bertrandias, A.; Steyer, J.-P.; Bernet, N.; Carrere, H. A vision of European biogas sector development towards 2030: Trends and challenges. J. Clean. Prod. 2021, 287, 125065. [CrossRef]

51. O'Connor, S.; Ehimen, E.; Pillai, S.C.; Black, A.; Tormey, D.; Bartlett, J. Biogas production from small-scale anaerobic digestion plants on European farms. Renew. Sustain. Energy Rev. 2021, 139, 110580. [CrossRef] 
52. Mainardis, M.; Goi, D. Pilot-UASB reactor tests for anaerobic valorisation of high-loaded liquid substrates in Friulian mountain area. J. Environ. Chem. Eng. 2019, 7, 103348. [CrossRef]

53. Stürmer, B.; Leiers, D.; Anspach, V.; Brügging, E.; Scharfy, D.; Wissel, T. Agricultural biogas production: A regional comparison of technical parameters. Renew. Energy 2021, 164, 171-182. [CrossRef]

54. Allah, W.A.; Tawfik, M.; Sagade, A.A.; Gorjian, S.; Metwally, K.; El-Shal, H. Methane production enhancement of a family-scale biogas digester using cattle manure and corn stover under cold climates. Sustain. Energy Technol. Assess. 2021, $45,101163$. [CrossRef]

55. Prabhu, A.V.; Avinash, A.; Brindhadevi, K.; Pugazhendhi, A. Performance and emission evaluation of dual fuel CI engine using preheated biogas-air mixture. Sci. Total. Environ. 2021, 754, 142389. [CrossRef]

56. Simsek, S.; Uslu, S. Investigation of the impacts of gasoline, biogas and LPG fuels on engine performance and exhaust emissions in different throttle positions on SI engine. Fuel 2020, 279, 118528. [CrossRef]

57. Hotta, S.K.; Sahoo, N.; Mohanty, K. Comparative assessment of a spark ignition engine fueled with gasoline and raw biogas. Renew. Energy 2019, 134, 1307-1319. [CrossRef]

58. Feroskhan, M.; Thangavel, V.; Subramanian, B.; Sankaralingam, R.K.; Ismail, S.; Chaudhary, A. Effects of operating parameters on the performance, emission and combustion indices of a biogas fuelled HCCI engine. Fuel 2021, 298, 120799. [CrossRef]

59. Legrottaglie, F.; Mattarelli, E.; Rinaldini, C.A.; Scrignoli, F. Application to micro-cogeneration of an innovative dual fuel compression ignition engine running on biogas. Int. J. Thermofluids 2021, 10, 100093. [CrossRef]

60. Abed, K.; El Morsi, A.; Sayed, M.; El Shaib, A.; Gad, M.S. Effect of waste cooking-oil biodiesel on performance and exhaust emissions of a diesel engine. Egypt. J. Petroleum 2018, 27, 985-989. [CrossRef]

61. Mofijur, M.; Rasul, M.; Hassan, N.; Uddin, M. Investigation of exhaust emissions from a stationary diesel engine fuelled with biodiesel. Energy Procedia 2019, 160, 791-797. [CrossRef]

62. Borah, M.J.; Das, A.; Das, V.; Bhuyan, N.; Deka, D. Transesterification of waste cooking oil for biodiesel production catalyzed by Zn substituted waste egg shell derived $\mathrm{CaO}$ nanocatalyst. Fuel 2019, 242, 345-354. [CrossRef]

63. Fonseca, J.; Teleken, J.G.; Almeida, V.D.C.; da Silva, C. Biodiesel from waste frying oils: Methods of production and purification. Energy Convers. Manag. 2019, 184, 205-218. [CrossRef]

64. Sahar; Sadaf, S.; Iqbal, J.; Ullah, I.; Bhatti, H.N.; Nouren, S.; Rehman, H.-U.; Nisar, J.; Iqbal, M. Biodiesel production from waste cooking oil: An efficient technique to convert waste into biodiesel. Sustain. Cities Soc. 2018, 41, 220-226. [CrossRef]

65. Lin, Y.-C.; Hsu, K.-H.; Chen, C.-B. Experimental investigation of the performance and emissions of a heavy-duty diesel engine fueled with waste cooking oil biodiesel/ultra-low sulfur diesel blends. Energy 2011, 36, 241-248. [CrossRef]

66. Kassem, Y.; Çamur, H. Effects of storage under different conditions on the fuel properties of biodiesel admixtures derived from waste frying and canola oils. Biomass Convers. Biorefin. 2018, 8, 825-845. [CrossRef]

67. Uddin, M.; Techato, K.; Rasul, M.; Hassan, N.; Mofijur, M. Waste coffee oil: A promising source for biodiesel production. Energy Procedia 2019, 160, 677-682. [CrossRef]

68. Mikulski, M.; Duda, K.; Wierzbicki, S. Performance and emissions of a CRDI diesel engine fuelled with swine lard methyl esters-diesel mixture. Fuel 2016, 164, 206-219. [CrossRef]

69. Sakthivel, G. Prediction of CI engine performance, emission and combustion characteristics using fish oil as a biodiesel at different injection timing using fuzzy logic. Fuel 2016, 183, 214-229. [CrossRef]

70. Adewale, P.; Dumont, M.-J.; Ngadi, M. Recent trends of biodiesel production from animal fat wastes and associated production techniques. Renew. Sustain. Energy Rev. 2015, 45, 574-588. [CrossRef]

71. Banković-Ilić, I.B.; Stojković, I.J.; Stamenković, O.S.; Veljković, V.B.; Hung, Y.-T. Waste animal fats as feedstocks for biodiesel production. Renew. Sustain. Energy Rev. 2014, 32, 238-254. [CrossRef]

72. Sakthivel, G.; Sivaraja, C.; Ikua, B.W. Prediction OF CI engine performance, emission and combustion parameters using fish oil as a biodiesel by fuzzy-GA. Energy 2019, 166, 287-306. [CrossRef]

73. Cunha, A.; Feddern, V.; De Prá, M.C.; Higarashi, M.M.; de Abreu, P.G.; Coldebella, A. Synthesis and characterization of ethylic biodiesel from animal fat wastes. Fuel 2013, 105, 228-234. [CrossRef]

74. Alptekin, E.; Canakci, M.; Sanli, H. Biodiesel production from vegetable oil and waste animal fats in a pilot plant. Waste Manag. 2014, 34, 2146-2154. [CrossRef] [PubMed]

75. Encinar, J.; Sánchez, N.; Martínez, G.; García, L. Study of biodiesel production from animal fats with high free fatty acid content. Bioresour. Technol. 2011, 102, 10907-10914. [CrossRef] [PubMed]

76. Kirubakaran, M.; Selvan, V.A.M. A comprehensive review of low cost biodiesel production from waste chicken fat. Renew. Sustain. Energy Rev. 2018, 82, 390-401. [CrossRef]

77. Wcisło, G. Analysis of the Impact of Rapeseed Varieties on the Properties of RME Biofuels and Diesel Engine Operation Parameters; FALL Publishing House: Krakow, Poland, 2013.

78. Kurczyński, D.; Łagowski, P.; Wcisło, G. Experimental study into the effect of the second-generation BBuE biofuel use on the diesel engine parameters and exhaust composition. Fuel 2021, 284, 118982. [CrossRef]

79. Raman, L.A.; Deepanraj, B.; Rajakumar, S.; Sivasubramanian, V. Experimental investigation on performance, combustion and emission analysis of a direct injection diesel engine fuelled with rapeseed oil biodiesel. Fuel 2019, 246, 69-74. [CrossRef]

80. Can, Ö.; Öztürk, E.; Yücesu, H.S. Combustion and exhaust emissions of canola biodiesel blends in a single cylinder DI diesel engine. Renew. Energy 2017, 109, 73-82. [CrossRef] 
81. Balamurugan, T.; Arun, A.; Sathishkumar, G. Biodiesel derived from corn oil-A fuel substitute for diesel. Renew. Sustain. Energy Rev. 2018, 94, 772-778. [CrossRef]

82. Chauhan, B.S.; Kumar, N.; Cho, H.M. A study on the performance and emission of a diesel engine fueled with Jatropha biodiesel oil and its blends. Energy 2012, 37, 616-622. [CrossRef]

83. Rao, Y.V.H.; Voleti, R.S.; Raju, A.V.S.; Reddy, P.N. The effect of cottonseed oil methyl ester on the performance and exhaust emissions of a diesel engine. Int. J. Ambient. Energy 2010, 31, 203-210. [CrossRef]

84. Habibullah, M.; Masjuki, H.; Kalam, A.; Fattah, I.M.R.; Ashraful, A.; Mobarak, H. Biodiesel production and performance evaluation of coconut, palm and their combined blend with diesel in a single-cylinder diesel engine. Energy Convers. Manag. 2014, 87, 250-257. [CrossRef]

85. Perumal, V.; Ilangkumaran, M. Experimental analysis of engine performance, combustion and emission using pongamia biodiesel as fuel in CI engine. Energy 2017, 129, 228-236. [CrossRef]

86. Rakopoulos, C.; Rakopoulos, D.; Hountalas, D.; Giakoumis, E.; Andritsakis, E. Performance and emissions of bus engine using blends of diesel fuel with bio-diesel of sunflower or cottonseed oils derived from Greek feedstock. Fuel 2008, 87, 147-157. [CrossRef]

87. Karabektas, M. The effects of turbocharger on the performance and exhaust emissions of a diesel engine fuelled with biodiesel. Renew. Energy 2009, 34, 989-993. [CrossRef]

88. Puhan, S.; Jegan, R.; Balasubbramanian, K.; Nagarajan, G. Effect of injection pressure on performance, emission and combustion characteristics of high linolenic linseed oil methyl ester in a DI diesel engine. Renew. Energy 2009, 34, 1227-1233. [CrossRef]

89. Özcanli, M.; Serin, H.; Saribiyik, O.Y.; Aydin, K.; Serin, S. Performance and Emission Studies of Castor Bean (Ricinus Communis) Oil Biodiesel and Its Blends with Diesel Fuel. Energy Sources Part A Recover. Util. Environ. Eff. 2012, 34, 1808-1814. [CrossRef]

90. Swaminathan, C.; Sarangan, J. A Comparative Study of Performance and Emission Characteristics of Biodiesel Blends with Diethylene Glycol Dimethyl Ether as Additive. Energy Sources Part A: Recover. Util. Environ. Eff. 2013, 35, 778-788. [CrossRef]

91. Çelikten, I.; Mutlu, E.; Solmaz, H. Variation of performance and emission characteristics of a diesel engine fueled with diesel, rapeseed oil and hazelnut oil methyl ester blends. Renew. Energy 2012, 48, 122-126. [CrossRef]

92. Nwafor, O. Emission characteristics of diesel engine operating on rapeseed methyl ester. Renew. Energy 2004, 29, 119-129. [CrossRef]

93. Chen, H.; Xie, B.; Ma, J.; Chen, Y. NOx emission of biodiesel compared to diesel: Higher or lower? Appl. Therm. Eng. 2018, 137, 584-593. [CrossRef]

94. Mofijur, M.; Masjuki, H.; Kalam, A.; Atabani, A. Evaluation of biodiesel blending, engine performance and emissions characteristics of Jatropha curcas methyl ester: Malaysian perspective. Energy 2013, 55, 879-887. [CrossRef]

95. Godiganur, S.; Murthy, C.S.; Reddy, R. 6BTA 5.9 G2-1 Cummins engine performance and emission tests using methyl ester mahua (Madhuca Indica) oil/diesel blends. Renew. Energy 2009, 34, 2172-2177. [CrossRef]

96. Nayak, S.K.; Pattanaik, B.P. Experimental Investigation on Performance and Emission Characteristics of a Diesel Engine Fuelled with Mahua Biodiesel Using Additive. Energy Procedia 2014, 54, 569-579. [CrossRef]

97. Qi, D.; Geng, L.; Chen, H.; Bian, Y.; Liu, J.; Ren, X. Combustion and performance evaluation of a diesel engine fueled with biodiesel produced from soybean crude oil. Renew. Energy 2009, 34, 2706-2713. [CrossRef]

98. Sureshkumar, K.; Velraj, R.; Ganesan, R. Performance and exhaust emission characteristics of a CI engine fueled with Pongamia pinnata methyl ester (PPME) and its blends with diesel. Renew. Energy 2008, 33, 2294-2302. [CrossRef]

99. Lemaire, R.; Béjaoui, S.; Therssen, E. Study of soot formation during the combustion of Diesel, rapeseed methyl ester and their surrogates in turbulent spray flames. Fuel 2013, 107, 147-161. [CrossRef]

100. Kousoulidou, M.; Fontaras, G.; Ntziachristos, L.; Samaras, Z. Biodiesel blend effects on common-rail diesel combustion and emissions. Fuel 2010, 89, 3442-3449. [CrossRef]

101. Randazzo, M.L.; Sodré, J.R. Exhaust emissions from a diesel powered vehicle fuelled by soybean biodiesel blends (B3-B20) with ethanol as an additive (B20E2-B20E5). Fuel 2011, 90, 98-103. [CrossRef] 